\title{
15. Yüzyılda Dâî? Tarafından Yazılmış Manzum Bir Fütüvvetname
}

\author{
A Poetic Futuvvetnama Written By Dâî? In $15^{\text {th }}$ Century
}

\begin{abstract}
Ali CíN*
Kübra AKÇAN**

Öz: Fütüvvetnameler, Türk edebiyatında 13. yüzyıldan itibaren ahlaki niteliklerin dinî kabuller doğrultusunda anlatıldığı, tasavvufi muhtevalı adap, erkân metinleridir. Fütüvvetnameler, sadece yazıldıkları dönemin inançları, kültürleri, örf, adet ve yaşayış biçimleri hakkında bilgiler sunmaz aynı zamanda dönemin edebî dili, söz varlığı, Türk dilinin ses, şekil ve imla bilgisi açısından da bize kaynaklık eder. Türk edebiyatında ilk örneklerini Arapça ve Farsça olarak gördüğümüz fütüvvetnamelerin 13. yüzyıldan itibaren Türklük coğrafyasında Türkçe manzum ve mensur biçimlerine rastliyoruz. Türk edebiyatında manzum olarak yazılan ve hacimli olarak kabul edilebilecek önemli fütüvvetnamelerden birisi de Marmara Üniversitesi Kütüphanesi Nadir Eserler Koleksiyonu 12881/Y004 numarada kayıtlı olan fütüvvetnâmedir. Eser, sebeb-i telifte yer alan bilgiye göre Hicrî 880/1475 yılında yazılmıştır. Eserde müellif ya da müstensih hakkında herhangi bir bilgi bulunmamaktadır. Eserde "țarsūs ehli bu işe ètmiş̧ heves / ba' $\dot{z} 1 S ı$ dā'iye ètdiler nefes"şeklinde geçen beyitteki Dai kelimesi oldukça dikkat çekicidir. Nüshanın baş ve son kısımlarında eksiklikler vardır. Aruzun "fâilâtün/fâilâtün/ fâilün" kalıbıyla harekeli olarak nesih türünde yazılan nüsha, genel olarak 15 beyitten oluşmaktadır. Eserin muhtelif yerlerinde ayetler, hadisler, Farsça şiirler ve Mesnevi'den örnekler verilmiştir. Dil hususiyetleri ve söz varlığına baktığımızda da, bu eserin 15.yüzyılın sonları 16. yüzyılın başlarında yazıldığı anlaşılmaktadır.
\end{abstract}

Anahtar sözcükler: Ahilik, manzum fütüvvetname, Fütüvvetname.

Abstract: Futuvvetnamas are sufistic texts which explain the moral characteristics in accordance with religious acceptance in Turkish Literature since the $13^{\text {th }}$ century. Futuvvetnamas are not only written to provide information on beliefs, culture, way of living and customs of the era in which they are written but also they are rich sources of literary language, vocabulary, Turkish language in terms of sounds, spelling and form. The first examples of Futuvvetnamas that we see in the Turkish literature are written in Arabic and Farsi. From the $13^{\text {th }}$ century onwards, we encounter poetic and prose forms written in Turkish language in Turkish geography. The Futuvvetnama which is catalogued in the Library of Marmara University's Rare Collections of Work of Arts is accepted as voluminous and written in prose and it is numbered as 12881/Y004. This work of art was written in the year of 880 according to the Hijri calendar. There is no information about the editor or copyist in the work. In this work of art, the word Dai is quite remarkable in the verse that runs as "țarsūs ehli bu işe ètmiş heves / ba' $\dot{z} ı s ı$ dā' iye ètdiler nefes". There are deficiencies in the beginning and in the ending of the manuscript. The manuscript which is written in the form of naskh and with the pattern of vowel points as "fâilâtün/ fâilâtün/ fâilün", is generally composed of 15 couplets. Examples of hadiths, verses from the Koran, Persian poems and Mesnevis are given in several times in this work of art.

Keywords: Akhism, poetic futuvvetnama, futuvvetnama

\footnotetext{
* Doç. Dr., Akdeniz Üniversitesi, Edebiyat Fakültesi, Türk Dili ve Edebiyatı Bölümü, Antalya, alicin@akdeniz.edu.tr

** Öğr. Gör., Antalya Bilim Üniversitesi, Antalya, kubra.akcan@antalya.edu.tr
} 


\section{Giriş}

Arapça bir kelime olan fütüvvet, "genç, delikanlı, yiğit" anlamlarındaki fetâ kelimesinden gelmektedir (Sami 2015, 981). Fütüvvet kelimesi ise "gençlik, delikanlılık; cömertlik; mertlik, yiğitlik" (Sami 2015, 982) anlamlarına gelir. Fütüvvet ehli Arapçada "fetâ, fityân", Farsçada "fütüvvet-dâr, cüvan-merd, fetâ" adlarıyla anılırken fütüvvet ehlinin yollarına Arapçada "alfutuva", Farsçada "fütüvvet" denilmiştir (Gölpınarlı 2011, 17). Türkçede ise fütüvvet ehli, "fetâ, ahi, yiğit, er, alp" diye adlandırılmaktadır. Tasavvuf kaynaklarında 8. yüzyıldan itibaren önde gelen sûfilerin fütüvvet kelimesini tasavvufi bir terim olarak kullanmaya başladıkları zikredilir (Uludağ - Ocak 1996, 259). Bu dönemden sonra fütüvvete, "dostların kusuruna bakmama, başkalarının haklarını ve çıkarlarını kendi menfaatinden üstün tutma, müslîm gayrı müslîm gözetmeksizin misafir edip, herkese bolca ihsanda, hürmette bulunma" gibi anlamlar yüklenmiştir (Uludağ - Ocak 1996, 259-260). O dönemlerde mert, cömert ve cesur bir kimsede bulunan vasıflar, gerçek bir sufide de bulunduğu için sufi aynı zamanda bir fetadır, Bu nedenle sufiler, fetayı "sufi", fütüvveti de "tasavvuf" olarak tarif etmekte bir mahsur görmemişlerdir (Uludağ Ocak 1996, 260). Sufilerde bulunan fedakârlık, yardım, iyilik, insan severlik, hoşgörü ve nefsine söz geçirme gibi ahlaki nitelikler zaman içerisinde tasavvufta, feta ve fütüvvet kelimelerinin karşıllı̆ı olmuştur (Uludağ - Ocak 1996, 260).

Fütüvvetnameler, çok eski çağlardan başlayarak faziletli ve alim şahsiyetler tarafından toplum düzenini ve güvenini sağlamak için verilen öğütlerin, ahlaki niteliklerin dinî inanç temelinde anlatıldığı tasavvufi metinlerdir. (Anadol 2001, 15). Fütüvvetname metinleri, daha sonraki dönemlerde Ahilik kurumunun temel ilkelerini ortaya koyan, yaşayış niteliklerini belirleyen ve insanlara içinde bulundukları toplumda ne şekilde davranmaları gerektiğini açıklayan dinî ahlaki nitelikli ögüt kitapları olarak tanımlanmıştır (Aydınlı 2011, 15). Bir ahinin, bir Müslümanın nasıl yaşaması, nelere dikkat etmesi, nelerden çekinmesi gerektiği ayetlerden, hadislerden, dinî hikâyelerden örnekler verilerek anlatılan bu metinler, temelde dinî tasavvufi mahiyette olmalarına karşın zaman içerisinde gelişerek üç kola ayrılmıştır (Ocak 1996, 264-265).

Bunlardan ilki 9-13. yüzyıllar arasında yazılan ve dinî tasavvufi mahiyette olup, tasavvufu ve onun çeşitli anlamlarını açıklayan Sufi fütüvvetnamelerdir (Ocak 1996, 264). İkincisi, 13-14. yüzyıllarda yazılan dinî tasavvufi mahiyetin yanı sıra bir nizamname mahiyeti de taşıyarak toplumdaki düzeni sağlaması bakımından önem arz eden fütüvvet teşkilatına ait fütüvvetnamelerdir. Üçüncüsü ise, 13-16. yüzyıllar arasında yazılan ve Ahî fütüvvetnameleri olarak ortaya çıkan fütüvvetnameleridir. (Ocak 1996, 264-265). Türk edebiyatında yazılan fütüvvetnameleri, Arapça ve Farsça Fütüvvetnameler ve Türkçe fütüvvetnameler şeklinde iki grup altında değerlendirmek mümkündür.

\section{Arapça ve Farsça Fütüvvetnameler}

Anadolu sahasında Arapça, Farsça yazılmış bilinen en eski fütüvvetname Hicri 4. asırda Ebu Abdurrahman Sülemî tarafından Arapça yazılan Kitâbü'l-Futuvva'dır (Gölpınarlı 2011, 21; Ateş 1977). Bilinen ikinci eser ise Hâce Abdullah-ı Ansârî̀nin büyük sufilerin sözlerini Arapça olarak alıp Farsçaya tercüme ettiği Fütüvvetnamesi'dir. (Gölpınarlı 2011, 21). Zikrettiğimiz her iki eser de Ayasofya Kütüphanesi 2049 numaralı Mecmua'da yer almaktadır (Gölpınarlı 2011, 21). Bunların yanı sıra yine aynı mecmuada dört risalenin dışında diğer risalelerin hepsi fütüvvete aittir. Bu mecmua, toplamda yirmi iki risaleden oluşmaktadır (Gölpınarlı 2011, 21). Mecmudaki önemli fütüvvet içerikli risaleler şunlardır:

Ali-ibn-el-Hasan-ibn-i Câdveyh'in Arapça yazdığı Kitâbu Mir'âtü'l-Muruvvât adlı risalesi, Selçuklu Devletinin veziri olan Nizamü'l-Mülk' e ithaf edilmiştir (Gölpınarlı 2011, 22). Ahmed 
b. Illyas el-Nakkaş el Harbutî’nin Arapça yazmış olduğu Tuhfetü'l-vesâyâ adlı eser, mecmuadaki sekizinci risaledir. Bu eser, Burgazî ve onu takip eden diğer Türkçe fütüvvetnamelere kaynaklık etmesi bakımından önem teşkil eder (Gölpınarlı 2011). Mecmuadaki onbeşinci risale, Halife Nâsır Lidinillâh'ın, elçilik vasitasıyla Anadolu'ya gelen Ebu Hafs Suhreverdî̀ye yazdırdığı Fütüvvetnâme'dir (Taeschner 1962). Suhreverdî, tasavvufî şahsiyeti ve eserlerinden dolayı, Anadoludaki fütüvvet teşkilatının gelişmesinde önemli rol oynamıştır (Sarıkaya 2002, 3). Mecmuada Suhreverdî’ye ait iki fütüvvetname bulunmaktadır (Gölpınarlı 2011, 22). Mecmuada yer alan Şihâbeddîn'in Kitâbü'l-Futuvva's1, Necmüddin Ebû Bekr Muhammed b. Mevdûd Tahir$i$ Tebrizî'nin Fütüvvetnâme'si ve müellifi bilinmeyen Kitâb-ı fi bahri'l-fütüvvati va zikru şacarati'-l-fayza da yine Farsça yazılmış fütüvvetnamelerdendir (Gölpınarlı 2011, 22). Bu mecmuadaki risaleler dışında Nâsırî adlı bir şairin farsça ve manzum olarak yazdığı fütüvvetname, İstanbul Üniversitesi Farsça yazmaları arasında kayıtlı olan ve şair Feridüdîn Attar'a nisbet edilen fütüvvetname ve Yahya oğlu Abdullah tarafindan istinsah edilen Murad Molla Kütüphanesi Abdulhamid 1. kitapları arasında 1447 numarada kayıtlı bulunan fütüvvetname de yine Farsça olarak yazılan önemli fütüvvetnamelerdendir (Gölpınarlı 2011, 23-24). 13. yüzyıla ait bu saydığımız eserler dışında, sonraki dönemlere ait çeşitli Arapça Farsça Fütüvvetnameler de mevcuttur (Torun, 1998, 48; Gölpınarlı 2011, 24-29). Fütüvvetnameler üzerine Hermann Thorning, Paul Kahle, Helmut Ritter, Fuat Köprülü, Osman Nuri Ergin, Muallim Cevdet gibi isimlerin de çalışmaları bulunmaktadır (Torun 1998, 48).

\section{Türkçe Fütüvvetnameler}

Fütüvvetnameler öncelikle Arap ve Fars Edebiyatında yer alan bir tür olup, oradan Türk Edebiyatına geçmiş eserlerdir. Anadolu sahasında bilinen ilk Türkçe Fütüvvetname, 13. yüzyılda yazılmıştır (Torun 1998, 48).

Günlük hayatın İslamî çerçevede nasıl yaşanması gerektiği hakkında bilgi veren fütüvvetnameler, Selçuklu ve Osmanlı dönemlerinde İslamiyet'in doğru anlaşılması ve yayılması bakımından büyük önem arz eder. Yazıldıkları dönemin inançları, kültürleri, tarihi, örfleri ve yaşayış biçimi hakkında bize 1şık tutan bu eserler, aynı zamanda dönemin edebî dili, söz varlığı ve gramer özellikleri bakımından da bizlere kaynaklık etmişlerdir. Fütüvvetnameler, herkesin anlayabilmesi için olsa gerek genellikle sade bir dille yazılmış eserlerdir.

Anadolu sahasında Türkçe fütüvvetnamelerin, mensur ve manzum olmak üzere iki biçimde yazıldığını görmekteyiz.

\section{Mensur Türkçe Fütüvvetnameler}

Mensur biçimde yazılan fütüvvetnamelerin bilinen en eski örneği Yahya b. Halil b. Çoban elBurgazî tarafından yazılan Burgazî Fütüvvetnamesi (Çobanoğlu Fütüvvetnâmesi) dir. Bu fütüvvetname, Anadolu sahasında Türkçe yazılmış fütüvvetnâmelerin bilinen en eski örneğidir. Eserin istinsah tarihi 913/ 1507 olarak bilinmektedir (Gölpınarlı 2011, 29). Eser Abdülbâki Gölpınarlı tarafından "Burgazî ve Fütüvvetnamesi" adıyla neşredilmiştir (Gölpınarlı 1953-1954, 76-153). Seyyid Gaybî b. Şeyh Hüseyin'in yazdığı Şeyh Seyyid Hüseyin Fütüvvetnamesi de bu alandaki Türkçe eserlerin ikincisidir. Bu fütüvvetnamenin içinde Fatih Sultan Mehmet için yazılan bir methiyenin olmasından dolayı, eserin Fatih döneminde yazıldı̆̆ düşünülmektedir (Gölpınarlı 2011, 29). Bu fütüvvetname de A. Gölpınarlı tarafından yayımlanmıştır (Gölpınarlı 1955-1956, 25 $155)$.

Anadolu'da yazılmış önemli fütüvvetnamelerden biri de Radavî'nin Fütüvvetnamesi'dir. Seyyid Muhammed b. Seyyid Alâaddin el-Hüseynî er-Radavî tarafından yazılan eserin birçok nüshası bulunmaktadır. Bursa'da kadılık yapan Seyyid Muhammed b. Seyyid Alâaddin Radavî’nin 
Miftahu'd-Dekâylk fi Beyâni'l-Fütüvveve'l- Hakâylk isimli fütüvvetnameyi 931/1524 başlarında yazdığı anlaşılmaktadır (Gölpınarlı 2011, 30). Miftah-ı Dekâyık ya da Fütüvvetname-i Kebîr olarak bilinen bu eser, yukarıda bahsettiğimiz eserlere göre çok daha hacimli, teferruatlı olması ve kendinden sonraki fütüvvetnamelere kaynaklık etmesi bakımından büyük bir önem arz etmektedir (Gölpınarlı 2011, 30; Torun 1998, 51-54). Eser Rahşan Gürel tarafından doktora tezi olarak çalışılmıştır (Gürel 1992). Daha sonra Sadullah Gülten ve Hacı Yılmaz tarafindan Fütüvvetname-i Kebir ismiyle yayımlanmıştır (Gülten - Yılmaz 2014). Ayrıca bu eserin içindeki bazı bölümleri (kemer bağlama töreni) ele alan bir nüshasını Fütüvvetname-i Tarikat ismiyle Osman Aydınlı çalışmıştır (Aydınlı 2011). Hâce-i Cân Ali Fütüvetnamesi (Hoca Cân Bursevî Fütüvvetnamesi) de Türk edebiyatındaki önemli fütüvvetnamelerden birisidir. (Torun 1998, 54). $\mathrm{Bu}$ Fütüvvetnamelerin dışında tercüme edilmiş yahut kısaltılmış Derviş Mim Ahmed Fütüvvetnamesi, Yâsin-i Rufâ'i Fütüvvetnamesi, Şeyh Ahmed Fütüvvetnamesi gibi daha birçok fütüvvetname de mevcuttur (Detaylı bilgi için bk. Torun 1998, 55-57). Zikretmiş olduğumuz eserlerin yanı sıra gerek Arap ve Fars Edebiyatında gerekse Türk Edebiyatında yazılan ancak müellifi çeşitli sebeplerden dolayı bilinmeyen fütüvvetnameler de vardır. Müellifi bilinmeyen fütüvvetnamelerden biri Fütüvvetname-i Ca'fer Sâdlk'dır. 16. yüzyılın sonlarında yazıldığı ve Bektaşîlere ait olduğu düşünülen bu eserin bilinen başka nüshası yoktur (Sarıkaya 2008). Müellifi bilinmeyen diğer fütüvvetname de 1229/1809 da yazıldığı düşünülen fütüvvetnamedir (Arslanoğlu 1997, 9-10).

\section{Manzum Türkçe Fütüvvetnameler}

Manzum şeklinde yazılan fütüvvetnamelerin bilinen ilk örneği, Şeyh Eşref b. Ahmed tarafından 856/1452 tarihinde istinsah edilen, aruzun fâilâtün fâilâtün fâilün kalıbıyla yazılan ve 444 beyitten müteşekkil fütüvvetnamedir (Bilgin 1992, VII). Türk edebiyatında bilinen manzum fütüvvetnamelerden bir diğeri de Esrar Dede adıyla bilinen Mevlevi Seyyid Muhammed b. Ahmed tarafindan 1211/1796 y1lında aruzun fe'ilâtün mefâ'ilün fe'ilün kalıbıyla yazılan ve 176 beyitten oluşan Esrar Dede Fütüvvetnamesi' dir (Torun 1998, 57; Yeniterzi 2001, 115-139). Eser, Hasan Kasır tarafından yayımlanmıştır (Kasır 1993, 107-130). Bu iki fütüvvetnamenin yanı sıra Eşrefoğlu Rûmî tarafından yazıldığı bilinen bir fütüvvetname daha vardır. Lakin bu esere ulaşılamamıştır (Torun 1998, 57). Bunların yanı sıra adı fütüvvetname olmamakla birlikte içerik bakımından fütüvvetname mahiyetinde olan ve müellifi bilinmeyen 25 varaklık manzum bir fütuhname Nuran Altuner tarafından çalışılmıştır (Altuner 1999, 23-38). Yine Süleymaniye Kütüphanesindeki bulunan üç yazma fütüvvetname Nuran Altuner tarafindan çalışılmıştır (Altuner 2005, 79-99). Ayrıca fütüvvetname içerikli bir manzume de Ömür Ceylan tarafindan şerh edilmiştir (Ceylan 2005, 223-247). Yukarıda adlarını zikrettiklerimizin dışında müellifi belli olmayan değişik kütüphanelerde daha birçok mensur ve manzum fütüvvetname mevcuttur. Fakat bunlar adını zikrettiğimiz fütüvvetnameler kadar büyük ve hacimli değildir. Bu fütüvvetnamelerin birçoğunun çeşitli fütüvvetnamelerin kısaltılmış şekli olduğu düşünülmektedir (Torun 1998, 57).

\section{Yüzyılda Dâî? Tarafından Yazılmış Manzum Fütüvvetname}

Üzerinde çalıştığımız ve müellifi bilinmeyen bu fütüvvetname, Marmara Üniversitesi Kütüphanesi Nadir Eserler Koleksiyonunda yer alan 12881/Y004 numarada kayitlı olan fütüvvetnamedir. Eser, 87 varaktan oluşmaktadır. Metinin baş ve son kısımlarında eksik varaklar vardır. Eser, Aruzun "fâilâtün/ fâilâtün/ fâilün" kalıbıyla harekeli olarak nesih türünde yazılmıştır. Eserde başlangıçtan 49. varağa kadar olan bölüm 15 beyitten oluşmaktadır. 49. varaktan sonraki kısım ise 13 beyitten meydana gelmektedir. Eserin muhtelif yerlerinde ayetler, hadisler, Farsça şiirler ve Mesnevi'den örnekler verilmiştir. Eserde verilen bu örnekler ve bölüm başlıkları kırmızı 
mürekkeple, yine harekeli biçimde yazılmıştır. Bir sayfadan diğerine geçişlerde bir sonraki sayfanın ilk kelimesi, takip kelimesi olarak kullanılmıştır. Metinde okunamayan, silik yahut karalanmış yerlere az da olsa rastlanmaktadır.

Üzerinde çalıştığımız fütüvvetnamenin başka bir nüshasına rastlanılmamıştır. Eserde maalesef müellif hakkında bir bilgi bulunmamaktadır. Sebeb-i telifdeki; țarsūs ehli bu işe ètmiş heves / ba'żISı dā'iye ètdiler nefes (9r5) beyitinde geçen Dāi kelimesi kütüphane kayıtlarında müellifin adı olarak yer alsa da bizce bu ihtimal düşüktür. Zira bu sözcügün kelime anlamlarından biri "şii-batınî mezheplerini yaymayı görev edinen, bu mezheplerin propagandasını yapan kişi” dir. Diğeri ise "olmasına, meydana gelmesine sebep olan şey" dir (Ayverdi 2008, 625-626). Eserin içerik bakımından dinî tasavvufi bir metin olduğu göz önünde bulundurulduğunda bu kelimenin müellifin adı değil de, yukarıda zikrettiğimiz anlamlarda kullanıldığı kanaatindeyiz. 15. yüzyılda Dâi mahlaslı iki şair bilinmektedir. Birisi klasik Türk edebiyatının önemli şairlerinden olan ve 14. yüzyılın sonu ile 15. yüzyılın başlarında yaşayan Ahmed-i Dâi' dir. (Özmen 2001, XXVII). Ahmed-i Dâi'nin eserlerine ve muhtemel ölüm tarihine (1421) (Kortantamer 1977, 133-134) bakıldığında, eserin Ahmed-i Dâi'nin ölümünden sonra yazıldığı anlaşılmaktadır. Diğeri ise yine 15. yüzyılda yaşadığı düşünülen ve ölüm ve doğum tarihleri bilinmeyen Kastamonu'lu Dai'dir. (Köksal 2002, 100-101) Bu iki şairin dışında 15. yüzyılda yaşayan Dâi mahlaslı bir şaire rastlamadık. Üzerinde çalıştığımız söz konusu metindeki şu iki beyit bize, eserin yazılış tarihi ile ilgili bilgi vermektedir:

çün sekiz yüz seksen oldı hicrete / geçdi sekiz ay dahı andan öte (8v14) bu kitābıy yazmasına başladım / bir gül idi șanki sükker aşladım (8v15)

$\mathrm{Bu}$ beyitlerden anlaşıldığına göre eser, Hicrî 880 yılının sonlarına doğru yazılmıştır. Bu tarih, Miladî 1475/ 1476 yıllarına yani 15. yüzyılın son çeyreğine tekabül eder. Dil hususiyetleri ve söz varlığına baktığımızda da, bu eserin 15.yüzyılın sonları 16. yüzyılın başlarında yazıldığı anlaşılmaktadır. Eserin nerede yazıldığıyla ilgili nüshamızda herhangi bir bilgi yer almamaktadır. Ancak sebeb-i telif bölümünde yer alan; țarsūs ehli bu iş̧e ètmiş heves / ba'żısı dā'iye ètdiler nefes (9r5) beyitinde țarsūs kelimesi geçmektedir. Burada adı geçen yerleşim yerinin günümüzdeki Mersin iline bağlı olan Tarsus ilçesi mi yoksa Suriye coğrafyasında yer alan Tartus (Tarsus) mu olduğu meçhuldür. Ancak müellif, eserini Tarsus ehlinin isteği üzerine yazdığını yukarıdaki beyitte ifade etmektedir. Ayrıca müellif, 51r13’te "anlaması vāżı̣̆ olsun deyüben /türkī yazdım çok'ibāret koyuban" şeklindeki ifadesiyle eserinin anlaşılmasının kolay olması için Türkçe yazdığını özellikle belirtir. Üzerinde çalışılan eserin baş kısmında eksik sayfalar vardır. Metin, ilahî yaratıcıya münacaatla başlamaktadır. Sonraki kısımda Hz. Muhammed'e ve Dört Halife'ye methiye vardır. Eserin yazılış tarihi ve sebeb-i telifinin anlatıldığı bölümden sonra, fütüvvetnameye başlanır. Fütüvvete girmeden önce uygulanan ritüeller, yedi bölümden oluşan peygamberlerin hayatlarından kıssalar ve şeyhlerin anlatıldığı bölüm olmak üzere üç ana bölümden oluşur. Müellif, " $b u$ fütüvvetname uş oldı tamām / yazup anı hațm ḳldık ve's-selām" (77v11) beyiti ile fütüvvetnameyi bitirir. Hemen arkasından "bāb-ı der-beyān-ı meşayıh-nāme ve șfathā ādābhā āb-ı sālik" isimli bir başlıkla yeni bir bölüme başlar. Bu bölüm içerik bakımından fütüvvetanameyle benzerlik göstermektedir. On varaklık bu bölümün ardından "bāb-ı der-beyān-ı meczzūb-ı sālik" adlı bir başlıkla farklı bir bölüme geçilir. Fakat ne yazık ki elimizde bu eserin yalnızca ilk varağı mevcuttur. $\mathrm{Bu}$ bölümlerden, üzerinde çalıştığımız fütüvvetname nüshasının Şeyh Eşref $b$. Ahmed'in Fütüvvetaname'si gibi bir mecmuanın içinde yer aldığı anlaşılmaktadır. Nitekim Orhan Bilgin, Şeyh Eşref b. Ahmed'in Fütüvvetnamesi'ni neşrederken eserin, sekiz mesnevili bir mecmuanın ikinci kısmında yer aldığını söyler. Bu fütüvvetnameden sonraki eserlerin isimleri, ibretname, elestname, nasîhatname gibi başlıklardan oluşmaktadır (Bilgin 1992, VII-VIII). Bu bilgilere 
bakarak üzerinde çalıştı̆̆ımız nüshanın da bu tarz bir mecmuada yer aldığı; nüshanın öncesinde ve sonrasında fütüvvetnameyle benzer içerikli mesnevilerin olduğu kuvvetle muhtemeldir.

Üzerinde inceleme yaptığımız eserde, fütüvvete dair ritüellerin anlatıldığı bölümler kısaca şunlardır: Sebeb-i telifden sonra Çile-dār Derviş Hikâyesi ve akabinde çeşitli beyitler ve hadislerden sonra der-beyān-ı fütüvvetname bölümüyle eser başlar. Bu kısımda, Fütüvvet ehlinin ilk ritüeli olan "tıraş olma"nın öneminden bahsedilir. édelim evvel tırāş-nāme sözin / çün ulular bu işi ḳıldı güzin (13v13). Beyitinten de anlaş1lacağ1 üzere, müellif bu bölümde tıraş olmanın önemini ve adabını anlatmıştır. İkinci Bölüm ise bu bölümün devamı niteliğinde olan " $b \bar{a} b-\iota$ der-beyān-ı makas-nāme" bölümüdür. Bu bölümde ise, saç kesmenin ehl-i fütüvvet için önemi anlatılmıştır. sünnetidür enbiyānın bu makas /șaçını kașr ède kim éde heves (21 v9).

Bu bölümün ardından "bāb-ı der-beyān-ı şedd-nāme" başlıklı, fütüvvetin en temel ritüeli olan ve fütüvvete girişi temsil eden "şedd kuşanma" yı anlatan bölüm gelmektedir. Zīrā şeddì aṣlı var bilmek gerek / ana göre olda şedd vérmek gerek (23r11).

Daha sonra sırası ile fütüvvetin diğer başlıca ritüellerinin anlatıldığ 1 bölümler zikredilir. Ritüellerin anlatıldı̆̆ 1 bu bölümlerden sonra altı bölümde bazı peygamberler (Hz. Adem, Hz. İbrahim, Hz. Yusuf...) çeşitli özellikleriyle zikredilmiştir. Yedinci bölümde ise hülafa-i raşidinden Hz. Ali anlatılmıştır. Bu eserdeki bölümler arasından tıraşname, makasname ve şeddname gibi bölümler gerek ritüellerin anlatılması gerekse bu isimler kullanılarak bir bölüm başlığı oluşturulması bakımından dikkat çekicidir. Üzerinde çalıştığımız fütüvvetname nüshası üzerine, Çukurova Üniversitesi, Temel İslam Bilimleri anabilim dalında Mustafa Topak tarafindan yüksek lisans tezi hazırlanmıştır. (Topak 2016) Tezin başlığı her ne kadar Ahi Dâ'î ve Türkçe Manzum Eseri: Fütüvvetname-i Tarsusî (İnceleme-Metin) şeklinde olsa da, Tezde incelemeye yer verilmemiştir. Çalışmada birinci bölüm girişten, ikinci bölüm fütüvvetnameler ve ahiliğin tarihçesinden üçüncü bölüm ise, nüsha üzerindeki genel değerlendirmeler, bazı kavramlar, tipler ve şahsiyetlerden oluşmaktadır. Tezin başlığından anlaşıldığı kadarıyla buraya kadar olan bölüm herhalde inceleme olmalıdır. Çalışmadaki bundan sonraki kısım, nüshanın transkribe edilmemiş metninden oluşmaktadır. Çalışmada en dikkat çekici cümle, dördüncü bölümde nüshanın tanıtımı ile ilgili zikredilen şu bilgi olsa gerek. "Beyitler alt alta değil, yan yana tertip edilmiştir." (Topak 2016, 64). Metin maalesef çok kötü okunmuştur. Bu çalışmayla ilgili eleştirilerimizi

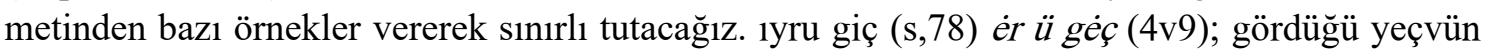
$(\mathrm{s}, 80)$ gördügi içün $(5 \mathrm{v} 2)$; tur-itdim $(\mathrm{s}, 81)$ töretdim $(6 \mathrm{r} 4)$; bön güninde $(\mathrm{s}, 83)$ bun güninde (6v10); her kez (s, 85) hergiz (7r15); usman (s, 86) osman (8r6); dürir (s, 87) durur (8v2); can dırur/kan dırur (s, 89) cān durur/ḳan durur (9r11); işle gel (s, 93) işlegil (10v8); olmese kim bule-ydi (s,100) olmasa kim buladı (13r14); eylediyu-ben (s, 111) eyle deyüben (17r9); putlarını sıybani oş! ide! (s, 229) bütlerini sıyıbanı uşada (63r6); sandın kitdi ödi (s, 232) șanadın gitdi ögi (64r7); k1lma bizi (s, 287) kılmaǵıl (87r9); hu dedüğünden (s, 97) hood yédüginden (12r12); lütfeyle gel / söyle gel (s, 287) lutf eylegil / söylegil (87r10)...

Eserdeki bazı kelimeler, bazen metindeki şekliyle bazen de günümüz Türkiye Türkçesindeki karş1lığı ile okunmuştur. Mesela, Eski Türkçede "ayna" anlamında kullanılan gözgü kelimesi, kimi yerde ayna olarak çevirilerek (Varlı̆̆a yokluk dürür ayna bilin / yok olanı şek değil ayna bilin $(s, 72)$ kimi yerde de, metindeki orijinal biçimi olan gözgü şekliyle okunmuştur. (gözgü olmuş idi buna Yusuf yüzi /Ahmed'i görürdi her gören gözi (s, 110). Yine "tezek, gübre" anlamındaki ters kelimesi bir beyitte ters biçimiyle okunurken diğer beyitte gübre şeklinde çevirilerek okunmuştur. (ters içinde oturir gördi özin / gübre idi hep "lot" deyu yediği s, 134). Bunun yanısıra şu kelimeler de, günümüz Tükçesine çevirilerek okunmuştur: efdal (s, 90) yegrek (12v3; iderek (s, 267) edü̈ben (78v4); hani ( $\mathrm{s}, 140)$ kanı (28r4). gübre (s, 134) ters (25v13)... 


\section{İnceleme}

Üzerinde çalışma yaptığımız fütüvvetamede imla, ses, şekil ve söz varlığına ait şu tespitlere ulaşılmıştır:

\section{İmla Fonetik}

İncelenen bu metinde hem ünlü işaretleri ('), (و), (ى) hem de hareke (üstün, esre, ötre) kullanılmıştır. Cezim işareti sıkça kullanılmış, şedde ve tenvin işareti ise cezime nisbeten daha az kullanılmıştır. Metin nesih hatla yazılmıştır. Ünlüler eserde hem harf hem de hareke ile gösterilmiştir.

\section{Ünlülerin Yazımı \\ a, e ünlüsü}

a, e ünlüsü ön seste medli elif (I) ile yazılmıştır. eyü (آيو) 11v14; aratmaz (آيدين) 8v8; aydın) $4 \mathrm{r} 1$.

a, e ünlüsü iç seste elif (I), (4) ve hareke (-) ile gösterilmiştir. dahı (داخى) 14r2;keselim (كسaلم) 81r6; her $(ه)$.

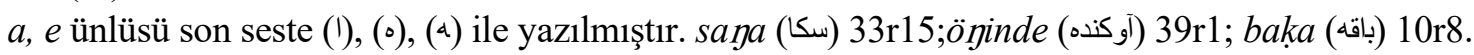

\section{I, i ünlüsü}

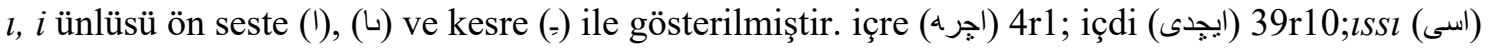
$11 \mathrm{r} 13$.

l, $i$ ünlüsü iç seste (ى) harfi ve kesre ()) ile gösterilmiştir. başını (بانشينى)18v8, ansız (انسز) 9r13 .

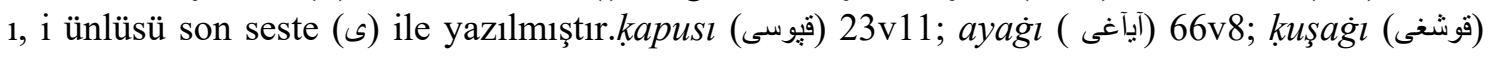
$35 \mathrm{v} 14$.

\section{o, $\ddot{\text { o, }} \mathbf{u}, \mathbf{u}$ ünlüleri}

$o$, o, u, ü ünlüleri ön seste (او) ve ötre (s) ile yazılmıştır. ögi (اونن) 64r7; un (اون) 75v5; ünin (اون) 50r9.

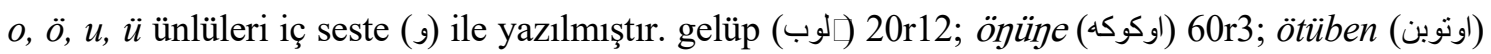
$50 \mathrm{r} 7$.

$o, \ddot{o}, u$, ü ünlüleri son seste (و) şeklinde yazılmıştır. ayru (ايرو) 21r8; delü (دلو) 23r6; alu (آلو) 28r11.

\section{Ses Olayları}

Metinde dikkat çeken ses olayları şunlardır:

\section{Yuvarlaklaşma}

Eski Anadolu Türkçesinde gördüğümüz ünlülerin yuvarlaklaşması ve üçüncü teklik şahıslardaki düzlük durumu incelediğimiz bu eserde de görülmektedir.

ayu 28v2; eyü 52v10; göndürür 44v10; özi 6v12; işidüp 39r11; yüzine 11v14.

Bilindiği üzere Eski Türkçe döneminde sonunda g ve g sesleri bulunan kelimelerde Bat1 Türkçesine geçişte bu sesler düşmüştür. Düşmenin sonucunda bazı kelimelerde yuvarlaklaşma meydana gelmiştir. Eserde bu kelimelerin bazılarının hem yuvarlak hem de düz biçimleri görüldüğü gibi, sadece yuvarlak biçimleri görülmektedir. bilümiz 45v2 / bili 69v3; kapu 24r2; kamu 8r3.

\section{Ek Uyumsuzluğu}

Metinde ek uyumsuzluğu görülen bazı kelimeler şunlardır: cömerdlık 34r13; ahillık 9v15.

Ünlü Birleşmesi

Ünlü birleşmesi görülen bazı kelimeler şunlardır: n'eyledi 25v10; n'ola 8r13; n’içün 42r14; n'etdi $61 \mathrm{v} 10$.

\section{Ünlü Düşmesi}

Metinde ünlü düşmesi görülen kelimelerin bazıları şunlardır: ag $(\imath) z ı n ~ 81 \mathrm{v} 1$; $a l(\imath) n \iota 15 \mathrm{v} 12$; as $(\imath) l \imath$ 
23r11; bag்(1)r1n 2r11; boy(u)na 44v7; buy(u)rug 14r4; oy(u)naya 34r15; üz(e)re 40r14.

\section{Ünsüz Düşmesi}

Eserde ünsüz düşmesi şu kelimede görülmüştür: eksicek "eksik olarak". akçesini eksicek vermeyesin 59r12.

e/è değişmesi

Günümüze kadar yapılan metin çalışmalarında /è/ ve /e/ yazımının nasıl olacağına dair bir birlik sağlanamamıştır. Bu nedenle de yapılan metin çalışmaları birbirinden farklı olmuştur (Cin 2012, 19-20). Eserde benzer kök hecelerin hem /è/ hem de /e/ şeklinde yazılımlarını görmekteyiz. Bu sebeple bu ses değişimi düzenli değildir. Bu ses değişiminin her iki biçimi de metinde görülmektedir. Hatta bazı kelimeler hem /è/ hem de /e/ şekilde yer almaktadır.

Metinde hem /è/ hem de /e/ şeklinde yazılan kelimeler: bez "bez": bèzdür 61 r11 bezin 61r10; de- "söylemek": dedi 18r2, deyüben 47r5; geç- "geçmek": geçdi 8v14 gęçe 23v12;gerçek " gerçek": gèrçek $60 r 6$ gerçek 5v10; et- "etmek": etmek $72 r 3$ ètdi $6 v 14$; ver- "vermek" : vérmeziz $41 v 15$ verdiler 36v13; yedi " yedi rakamı": yédi 23v3 yedi 23v9; yeg "iyi, daha iyi": yeg 60r15, yegdir 46r13; yet- "yetişmek": yetdi 43v11 yetmese $6 r 11$.

Metinde sadece $/ \dot{e} /$ şeklinde yazılan kelimeler: bel "bel": bèl 22v13; gece "gece": géce 10r11; eşik "kapı": ęşigine 22v15;yel- "koşmak, hızlı gitmek": yèlüben 70v13.

Metinde sadece kök hecede /e/ şeklinde yazılan kelimeler: çek- "çekmek": çekdi 17v10; beş "beş": beşi 65v9: deril- " toplanmak": derrildiler 36v13 dev " dev": dèv 57v7; ev "ev": evi 64r7.

\section{Ünsüzlerin Yazımı}

Arap alfabesinde $/ p /, / c ̧ /, / \eta /$ sesleri bulunmadığ 1 için metinde bu sesler (ك), (ج), (ب) harfleri ile gösterilmiştir. Metinde /ç/ (飞) ve /p/ (ب) seslerinin ayrımı yapılmamakla birlikte kullanımda bir istikrar yoktur. /ç/ ünsüzü bulunan sözcüklerde bu ses genellikle $c$ (ج) olarak yazılmıştır. Bir kaç örnekde ise ayrım yapılarak ç (ङ) biçiminde gösterilmiştir: üç (اوج) 75v6; akçe 25r15. Bununla birlikte asıl kelimede $c$ (ج) olması gereken ünsüzlerin birkaçı da $c$ (ङ) şeklinde yazılmıştır.

Aynı durum /p/ sesi için de geçerlidir. $P(\hookrightarrow)$ ünsüzü, bulunduğu sözcüklerde, bir kaç istisna dışında $b$ (ب) şeklinde gösterilmiş, bu harfin de ayrımı yapılmamıştır: ḳılup (قبلوب) 4v8; geyüp (كيوب). Buna ek olarak kelimede $b$ (ب) olması gereken bazı sözcükler $p$ (ب) harfiyle yazılmıştır: bi-çare (جاره) 85r3.

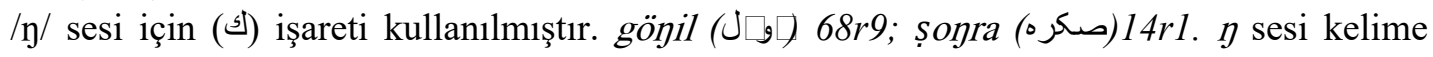
sonlarında (ك) ile yazılmıştır. bin (بكيك) 16r12; senin (سنك) 70r3.

Eserde /k/, /g/ ayrımı da yapılmamış; "g" (ङ) sesi “k" (ऽ) ile yazılmıştır. gelen(ن)7r4; gök (ك) 17rl; kesdi (سند)12r15.

Eserde bazı kelimelerin hem art damak n'si hem de art damak n'siz biçimleri geçmektedir. ansızın "birdenbire, aniden" ansizın 5v11/ ansizın 12r6; bun "sikıntı" buy 6v10/ bun 32r12; dinle- "dinlemek" dinlegil 35r4/ dinledi 74v13; dön- "dönmek" döndi 31r5/ döne 72r10; ön "ön, ön taraf" öndin 22v6/ önde 86v11. Eserde geçen sat (ص) ve sin ( $\square$ ) harfi ile yazilan kelimelerde istikrar görülmektedir.

\section{Ünsüz Değişmeleri}

Metinde görülen ünsüz değişmeleri şunlardır:

\section{t/d değişmesi}

Bu değişme metinde birçok kelimede görülmektedir. Metinde bazı kelimeler hem /ț/li hem de /d/ li biçimde yer almaktadır. șag ayaġın $a d a$ allāh adıla 39v1/ bir adımın atd $\iota$ allāh ad ile 30r11; pes bişirdi közine gitdi dütün 12r14/ gözüne girmeye țamuda tütün 21v4; pādişāhı̣ bir oḳı dutar ḳurduġın 36r4 / luṭf èdüp ḳulaḳ țutasin sen dahı 9v13.

Günümüz Türkçesinde/t/li olarak kullanılan bazı kelimler, metinde /d/li biçimde geçmektedir. 
üstime ditrer idin og̉ul deyü 33r13; dilkülenüp dünyāsın irdemesün 61r6; şed iki dürlü durur bil ey ah̄i $38 \mathrm{r} 11$.

Bugün /d/li olarak kullandığımız kelimelerin bir kısmı ise, metinde /t/li biçimde kullanılmıştır. țag u țaş ova vü șaḥrā ḳomadı 28r6; sünnīler țag̉ılmışıdı her biri 72v11; içi leylā vü țısı leylā idi 27v11; țuydı mıṣr ehli ḳamu hātun işin 67r9; aç toyurğ $l$ yāhū yalıncak tonat 46r14; bulma-

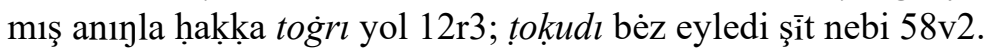

\section{$\mathbf{k} / \mathbf{h} d e g ̆$ işmesi}

Türkçe kelime başında /h/ sesi bulunmadığ 1 için günümüzde /h/ ile başlayan kelimeler Eski Türkçe döneminde / $/$ / sesi ile başlamaktaydı (Özkan 2013, 107-108). Eserde bazı /ḳ/ sesleri kendin korurken bir kısmı /h/ sesine dönüşmüştür. Bazı kelimeler ise hem $/ \mathrm{k} /$ sesiyle hem de $/ \mathrm{h} /$ sesiyle kullanılmıştır.

\section{Kelime başında $\mathbf{k}$-/h- değişmesi}

$\mathrm{Bu}$ değişme metinde sadece hatun kelimesinde görülmektedir. Eski Türkçede ḳatun biçiminde olan kelime eserde ḩatun şeklinde geçmektedir. aldı ḩātun yūsufı çoḳ vẻrdi māl 67r6; yūsuf ạladı ki hătun ḳașdı ne 68r11.

\section{Kelime ve hece ortasında - $\mathbf{k}-/-\mathbf{h}$ - değişmesi}

Metinde bu değişmeyle ilgili üç örnek bulunmaktadır. "akşam” ve "okşa- " kelimeleri yalnızca /h/ biçiminde metinde yer alırken "akçe" kelimesi hem /h/ hem de /ḳ/ biçiminde kullanılmıştır. ahşam oldı niyyet ètdi nežr içün 75v2; ohşayuban derdi ey dürr-dānesi 63v1; gözi şeyhin altun ile ahçede 25r14 / şeyh olanın yolı bin akçe tamām 44r13.

\section{Kelime ve hece sonunda $-\mathbf{k} /-\mathbf{h}$ değişmesi}

$\mathrm{Bu}$ değişmeyle ilgili iki örnek bulunmaktadır. Bu kelimeler yoh/yok ve tah-/ tak- kelimeleridir. Her iki örnekte de kelimeler hem /h/ hem de / $/$ / biçiminde kullanılmıştır. yohsa bu zaḥmet içinde ḳalasın 46v5 / dervịs isen kimsede yoḳdır işin 19r2; ya' nī tācum taha tācın senin 18v11 / takdı bir ip așdı mūsā boynına $44 r 7$.

\section{b/v değişmesi}

Eski Türkçe döneminde kullanılan bazı kelime ve fiillerin başındaki /b/ ler Batı Türkçesinde /v/ olmuştur. Bu ses değişimi metinde, Eski Anadolu Türkçesinde görülen 1. Teklik şahıs eki olarak kullanılan "van-ven” biçiminde kullanılır. çün resūlu'llāh dėdi benven fetā $74 \mathrm{r} 1$.

\section{-g/-y değişmesi}

Bugün /y/li biçimde kullandığımız bey kelimesi metinde beg şeklinde kullanılmıştır. ahi begler kapusina varmaya $51 \mathrm{r} 9$.

\section{-g-/-v- değişmesi}

Eserde -g-/-v- değişmesiyle ilgili olarak birkaç örnek bulunmaktadır. Kelime içinde genelde /-g/ li biçimler kullanılmıştır. ya ne guușșa anı çünkim dögeler 84v7; ahī sögse olmaya hịç göyli țār $22 \mathrm{v} 8$; öge öge bézi șatdı yigide 61v11; kimi yunır kimisi de ovunur 70v3.

\section{- $\dot{\mathbf{g}}-/$-v- değişmesi}

Eski Türkçe döneminden /g/ $/ 1$ biçimde kullanılan kllavuz kelimesi metinimizde de / $\dot{\mathrm{g}} / 1 \mathrm{l}$ biçimde kullanılmıştır. kulag̉uz sen ol bize yār-1 hudā 62r13.

\section{-ḳ-/-g'- değişmesi}

Bu değişme metinde birçok kelimede görülmektedir. Bazı kelimeler hem $/ \dot{\mathrm{g}} / \mathbf{l}_{1}$ hem de $/ \mathbf{k} / \mathbf{l}_{1}$ biçimde yazılmıştır.

gavg்adır bu üstimizden șavalım 82v6; yėmek içün bunda ḳardaş çog olur 34v10 / kimi otuz kimi dahı çok olur 36r3; gönli alçag idi vü ḳadri yüce 7v4 / ol țaşa alçak yüzinden söyledi 44r3; andan alınanda dört yaprag idi 19r8 / agaca dèdi vẻrin yaprak bana 41v15.

Eski Anadolu Türkçesinde ünsüzle biten kök ve gövdelere gelen tonlu ünsüzlü yapılar bu metinde de yaygın biçimde görülmektedir. bir adımın atdı allāh ad ile 30r11; ol zamān kim 
ādem $u c ̧ m a k d a$ idi 48v1; șāfiyi anmaḳlıg̉a $a c ̧ d ı$ ḳapu 25v6; pes bişirdi gözine gitdi dütün 12r14; dünyāya gelicegiz gözetdi ol 55r10.

Morfoloji

Ayrılma durum eki metinde genel olarak -dan/ -den biçiminde geçmektedir. Ancak -dın/-din'li şekildeki kullanımı da metinde iki yerde görülmektedir. çünki sende varlıg்dan zerre var 2v11; derdi olmayan kişi hakkkdan ırak 3r3; 62v1; yūsufın bu kısșasından ḳıșa al 66r1; şüphesi olsa bilendin șora ol 10v2; yėmek olsa halḳdan öndin yemeye 22v6.

Metinde cihet eki -ra, -re, -aru, -erü, -arı biçiminde görülmektedir. țola idin 'ālem içre ad ile 2r12; ya' nī yetmişden yukarı olmaya 22r15;țur yukaru sen dahı bag̉la bèli 35v1.

Eski Türkçe döneminden Eski Anadolu Türkçesi dönemine kadar -matı/-meti; -matın-metin şeklinde kullanılan zarf-fiil eki metinde madın/-medin şeklinde görülmektedir. ḳazıya kurutmadın tīz yaşını17v1; şeyh anı gözler idi görmedin 61v12; büyümedin sen ānı̀ ḳaydın yègil 63r5; değmedin başına ustura sitiz 16v9.

Metinde -uban/-üben zarf-fiili yanında -ubanı/ -übeni biçimi de görülmektedir. baturuban dürr ü cevher altuna 66v12; başını kalduruban baḳmaz idi 68r2; varuban sen alasın andan sebak 69r7; gelüben ol otura sen kesesin 22r5; getürüben pïr öyinde șoralar 44r10; ol güle ḳarşu ötüben söyledi 50r7; yazubanı sözi tekmīl èdeyim 79v10; pirr-i ma' nā kalkubanı aṣılur 83v11; leylā leylā deyü beni dizilür 29r1.

Metinde -(y)up/-(y) üp; -ıp/-ip;-p zarf-fiil ekleri de sıkça görülmektedir. şeyh oturup gözler anıy n'ètdügin 59v10; dükkānıma geldin alup gitmegil 60r8; șoyra anı çıkarup geye ' abā 60v10; țurmayup ol leşkeri gezüp țurur 72v3; 'aşk ile varıp baḳavuz ol yüze $87 \mathrm{v} 3$; kavşurıp el țura dā 'im țāpuda 22v4; bişürip halvāyı çengel ètdiler 36v15; kudretin diliyle gel dép söylegil 87r10.

Eserde -ıcak/-icek zarf-fiil ekisıkça kullanılmıştır. açıcak bir nūr zāhir oldı tīz 16v9; halk yanıcak aya hiç èrmez tütün 21v5; oturıcak 27v12; üstime toz konıcak ağlar idin 33r11.

Metnimizde -ınca/-ince zarf-fiil eki de yer almaktadır. hadd urınca işidirlerdi sözin 81v6; èrte olınca bular gör n'ètdiler 84r6; nefes yanınca gider hār u hası 2r14; kim seni görince peygamber bile $32 \mathrm{v} 10$.

Metinde - $d \imath k c ̧ a /$-dikçe zarf-fiil eklerinden yalnızca -dikçe biçimine bir kelimede rastlanmıştır. bildikçe ben de birḳaç söyledim 9v11; bildikçe yazdım anı ben dahı 10v8.

Eserde -arak/-erek zarf-fiil ekinin bu dönemdeki birçok eserde görülen şekli olan -ü zarffiilinden -rek, -rak ile genişletilmiş olan -urak/-ürek (Özkan, 2013, 152-153) şeklindeki kullanımı metinde bir kelimede geçmektedir. ag̉layurak dèdi mecnūn ey cuvān $28 \mathrm{v} 5$, ag̉layurak dèdi ey cānım cānı 33v12.

Eski Anadolu Türkçesi eserlerinde görülen, benzerlik bildiren -cllayın/-cileyin eki metinde yalnızca iki kelimede kullanılmıştır. buncalayın sözi baya söylemen $82 \mathrm{r} 9$; git beni de sencileyin eyleme 33 r5.

Eski Anadolu Türkçesi döneminde gelecek zaman eki olarak kullanılan -ısar/-iser eki çalıştığımız metinde de görülmektedir. her ki küstāh ise maḥrūm olısar 48v13; èrmeyüben menzile ol kalısar 48v13; degiserdir şimdi uş yine kime 31r2.

Eski Türkçeden bu yana kullanılan 2. Teklik şahıs emir eki -g̈ll/-gil, metinde hep düz biçimde kullanılmıştır. ḳuvvetin yètdügi neyse söylegil 75r9; miskīni vü hem yetīmi gözlegil 76v12; pīr èşiginde țuruban ag̉lağıl 22v13; git gèrü leylāya neşter urma $\dot{g}_{l} l 28 \mathrm{v} 7$.

Eserde gereklilik kipi olarak bu dönemde yazılan metinlerde de sıkça rastladığımız gerek kelimesi ve -e/-a istek kipini alan fiilerin, bu kelime ile kullanılmış hali olan -e gerek / - a gerek kullanılmıştır. ne'yleyüp nice yola gitmek gerek 23r2; hakk yolında sana gerek custucū 24v2; hidmet èden hidmete èrse gerek 22v11; öyle mi gerekdir ey tanrı kulı 50v12.

Metinde -acak/-ecek ekinin dört yerde gelecek zaman sıfat-fiil olarak kullanıldığı görülmek- 
tedir. yaykanacak yer dahı bulmayasın 70r7; bilmeyecek ètdügi gavġā nedür 38v11; dönecek vaḳtin dèdi kim ey kişi 53r13; yeyecek yoḳ ahşşam oldı çün yaḳın 75v4.

$\mathrm{Bu}$ ek, bir örnekte ise gelecek zaman eki olarak görülmektedir. n'édeceksin èt baya 42v2.

Eski Anadolu Türkçesinde birinci çokluk şahıs eki olarak gördügümüz -vuz/-vüz'lü yapılar bu eserde de görülmektedir. Metinde -uz/-üz'lü yapılardan ise sadece bir örnek görülmektedir. yol varana varavuz yalvaravuz 31v4; biz dahı bakışmayavuz dört yana 55r4; azmayup kayıkmayavuz dört yana 62r12; dostlarıjla oynayavuz gülevüz 49r9; toġn ādemler yolına gidevüz 58r1; biz dahı görünmeyevüz ol göze 79r5.

Üçüncü kişi zamiri metinde "ol" şeklinde geçerken bir örnekte $o$ şeklinde geçmektedir. evliyāya hem $o$ olmuşdır delil 8r15.

Eserde küçültme eki olarak -cık; -cek;-cug ekleri kullanılmıştır. hem kıısacıkişleme sen bu işi 60r2; bir yol üzre bir karıcık oturur 72r5; karıcuga nesne vërürler idi 72r8; akç̧esini eksicek vermeyesin 59r12; tìzcek așıl çoḳ da' vā eyleme 83v10.

Eski Anadolu Türkçesinde görülen bile, ile beraberlik bildiren edatları eserde kullanılmıştır. Bunlara ek olarak bile ekinin üzerine ekvatif (eşitlik) eki olan -ca/-ce eki getirilerek bilece şeklinde de kullanımı da bir yerde görülmektedir. hakk yolına bile yoldaş oldılar 33v8; anlarupla bile yoldaş eylegil 36r7; anın ile gitdi bülbül bile 49v7; her işinde bilece yoldaş idi 33v7.

Metinde kullanılan $b u$ zamirinin çokluk şeklinde zamir n'sinin düşerek bular şeklindeki kullanımı bir örnekte görülmektedir. hakk resūlinden bular vèrdi haber 13v15; dahı envā'-i cevāhirden bular 15r7; ma' nāda birdür bular ayrı değil 29r13.

\section{Söz Varlı̆̆ı}

Üzerinde çalıştığımız fütüvvetname dil özellikleri bakımından Eski Anadolu Türkçesi özellikleri gösteren bir eserdir.

Eserin söz varlığı Eski Anadolu Türkçesi metinlerinin söz varlığına benzer bir söz varlığına sahiptir. Metinde Eski Türkçe dönemine ve diğer lehçelere ait kelimeler de görülmektedir. Bu döneme ait kelimelerin bazıları şunlardır: kanı 16v15; kanda 7v11; kandan 48v8; kankı 55r7; kancaru 40v1; ıssı 11r13; uş 13v11; konuk 59r1; genez 81v7; yarag 15r8; yavuz 61v1; alda61r4; kiçi 7r12.

Eserde bazı kelimelerin hem düz hem de yuvarlak biçimleri kullanılmıştır. ayrı 29r13 / ayru 18v14; bildir- 35r12/ bildür-21v1; bili 69v3/ bilü 45v2; bişir-12r14/ bişür- 36v5; büyik 15r11/ büyük 63v8; ètdir- 1v10/ ètdür- 57r8; eylik 3v15/ eylük 57r1; fāslk 87v8/ fasūk 11r4; gèri 81r7/ gèrü 18v1; gizli 13r8/ gizlü 38r9; ylldız 23v6/ yılduz 23v5.

Eserde gövde ve tövbe kelimesi yalnızca düz biçimleriyle kullanılmıştır. gevde 28r2; 28v9, $83 \mathrm{v} 12$; tevbe $4 \mathrm{v} 8,4 \mathrm{v} 9,35 \mathrm{v} 15,36 \mathrm{r} 1$.

Eserde geçen ikilemeler şunlardır: öge öge "öve öve, överek" 61v11; dürlü dürlü "çeşit çeşit" 51r3, 70r8; ève ève "aceleyle, hızlı hızlı" 65r4, 68r7, 73r10; ura ura "vura vura" 36v5; ardın ardın "arka arka, geri geri" 53v12, 53v13; üçer üçer "üçer üçer" 75v1; birin birin "tek tek, sırasıyla" 46r3; bölük bölük "bölük bölük, kısım kısım" 86v7.

\section{Sonuç}

Müellifi bilinmeyen bu fütüvvetname, Türk edebiyatında yazılan diğer fütüvvetnamelerle muhteva bakımından benzerlik göstermektedir. Üzerinde çalıştığımız metin, eserin yazıldığı döneme ait dinî, kültürel ve sosyal bilgiler içermenin yanı sıra, o dönemin dil hususiyetleri hakkında da veriler barındırmaktadır. Eserde fütüvvetnameye dair birçok terim de görülmektedir. Nüshanın en önemli hususiyetlerinden birisi de, bilinen manzum fütüvvetnameler içerisinde en hacimli olan fütüvvetname olmasıdır. Elimizdeki metin imla, ses ve şekil bakımından incelendiğinde şu sonuçlara ulaşılmıştır: 
Üzerinde inceleme yaptığımız müellifi bilinmeyen fütüvvetnamenin dil özellikleri bakımından Eski Anadolu Türkçesi döneminde yazılan diğer eserlerle benzerlik gösterdiği sonucuna varılmıştır.

/ç/ (ङ), /p/ (ب) ünsüzlerinin yazımında birkaç istisna dışında ayrım yapılmamış, bu sesler $c$ (ج), $b$ (ب) (ج) biçiminde gösterilmiştir.

Üzerinde çalıştığımız söz konusu metinde, $/ \mathrm{k} /-\mathrm{g} /$ ayrımı yapılmamıştır. Her iki ses için de (5) kullanılmış; aynı şekilde $\eta$ sesi de yine ( ك) ile yazılmıştır. Ayrıca eserdeki bazı kelimelerin hem art damak n'li hem de art damak n'siz yazımı mevcuttur.

Eserde kelime başındaki $t$-/ $d$ - değişmesi birçok kelimede görülmektedir. Metinde bazı kelimeler /t/ li biçimde yazılırken, bazıları /d/ ye dönüşmüştür. Bazı kelimelerin ise hem /t/ li hem de /d/li biçimleri görülmektedir.țaġll-;țamar; dilkülen-;diri; țag̀la-/ daġla-; tütün/dütün.

Eski Anadolu Türkçesinde kelime başındaki bazı /ḳ/ sesleri /h/ ya dönmüştür. Metinimizde $k$-/h- değişmesi yalnızca "hâțun" kelimesinde görülürken "ḳanḳı, ḳanı, ḳanda" gibi kelimelerde k sesi varlığını korumuştur.

Eserde - $k-/-\dot{g}$ - değişmesi birçok kelimede görülmektedir. Kelime sonunda bulunan k sesi, ünlü ile başlayan bir ek aldığında tonlulaşarak / $/ \mathrm{g} /$ ya dönüşmüştür. Ayrıca ek almadan bu değişime uğramış kelimeler de vardır. Bu kelimeler metinde, hem / $/ l_{1}$ hem de / $\mathrm{g} / 1_{1}$ biçimde

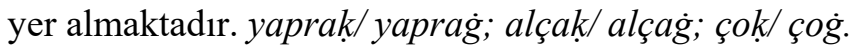

Eser, $-e-/ \dot{e}$ - değişmesi bakımından kapalı /è/ tarafindadır. Metinde açık /e/ çok az kelimede geçmekle birlikte bazı kelimeler de hem /è/ hem de/e/ şeklindeki kullanımları görülmektedir. Bu kelimeler şunlardır: bèz/bez; gèrçek/ gerçek èt-let-;ver-/ver-.

Eserde ayrılma eki genel olarak -dan/-den yaygın biçimde kullanılmıştır. nitelikden 1v2; felekden 1v9; varligdan 2v11; hakkdan 3r3.

Metinde zarf-fiil eki olarak -uban/-üben; -ubant/-übeni;-madın/-medin; -(y)up/-(y) üp; -ıp/ip;-p -ınca/-ince ve -ıcak/icek kullanılmıștır. baturuban 66v12; kalkubanı 83v11; deyübeni 29r1; görmedin 61v12; bişürip 36v15; dèp 87r10; açıcak 16v9.

Eserde, -acak/-ecek 4 yerde gelecek zaman sıfat-fiil olarak kullanılmıştır. yaykanacak 70r7; dönecek 53r13.

Gelecek zaman eki olarak -isar/-iser metinde 8 yerde geçmiş; -acak/-ecek eki de 1 yerde gelecek zaman eki olarak kullanılmıştır. ḳalısar 48v13; n'édeceksen 42v2.

Metinde gereklilik kipi olarak gerek, -(s)e/-(s)a gerek, -mek/-mak gerek kullanılmıştır. gitmek gerek 11r1; bulmak gerek 79r9; görse gerek 22v11

Birinci çokluk şahıs eki olan -vuz/-vüz, eserde 15 yerde geçmiştir. varavuz 31v4; olavuz 49r9; bakış̧mayavuz 55r4

Doğu Türkçesinde en çok bol-, kll- şeklinde görülen yardımcı fiillerden, eserimizde en sık kullanılanı ol- yardımcı fiilidir. Söz konusu fiil eserde, 172 yerde yardımcı fiil olarak kullanılmıștır. èt- yardımc1 fiili 149, eyle- 113, kll- 61; verr- ise yerde yardımcı fiil olarak kullanılmıştır. Bunların yanı sıra, kal-, țr-, gel-, gör- gibi yardımcı fiillerin de kullanımı görülmektedir. 


\section{KAYNAKÇA}

Akkuş M. (2005). "Edebiyatımızda Ahi Tipi ve Esrar Dede Fütüvvetnâmesinde Ahi Tipinin Özellikleri”. Haz. M. F. Köksal, Ahi Evran-ı Velî ve Ahilik Araştırmaları Sempozyumu I (2005) 15-25. Kırşehir.

Akpınar A. (2005). "Fütüvvetin Dinî Temelleri”. Haz. M. F. Köksal, Ahi Evran-ı Velî ve Ahilik Araştırmaları Seтроzyumu I (2005) 43-61. Kırşehir.

Altuner N. (1999). "Manzum Bir Fütûhnâme". II. Uluslararası Ahilik Kültürü Sempozyumu Bildirileri (1999) 23-38. Kırşehir.

Altuner N. (2005). "Süleymaniye Kütüphanesinde Yazma Üç Fütüvvetname”. Haz. M. F. Köksal, Ahi Evran-ı Velì ve Ahilik Araştırmaları Sempozyumu I (2005) 79-99. Kırşehir.

Anadol C. (2001). Türk-İslâm Medeniyetinde Ahilik kültürü ve Fütüvvetnâmeler. Ankara 2001.

Arslanoğlu İ. (2005). "Fütüvvetnameler ve Bir Fütüvvetname". Haz. M. F. Köksal, Ahi Evran-ı Velî ve Ahilik Araştırmaları Sempozyumu I (2005) 101-118. Kırşehir.

Arslanoğlu İ.(1997). Yazarı Belli Olmayan Bir Fütüvvetnâme. Ankara 1997.

Ateş S. (1977). "Es-Sülemî Ebû Abdi'r- Rahman Muhammed b. el- Huseyn, 'Kitâbu'l-Fütüvve, Tasavvufta Fütüvvet"”. Vakıflar Dergisi (1977).

Aydınlı O. (2011). Abdulganî Muhammed b. Alâuddîn el-Huseynî Radavî, 'Fütüvvetnâme-i tarikat'. Ankara 2011.

Ayverdi İ. (2088). Misalli Büyük Türkçe Sözlük. İstanbul 2008.

Banguoğlu T. (2015). Türkçenin Grameri. Ankara 2015.

Bilgin O. (1992). Şeyh Eşref b. Ahmed- Fütüvvetnâme. İstanbul 1992.

Bozkurt F. (2006). Buyruk. İstanbul 2006.

Ceylan Ö. (2005). "Fütüvvetnâme Muhtevalı Bir Manzume Şerhi”. Haz. M. F. Köksal, Ahi Evran-ı Velî ve Ahilik Araştırmaları Sempozyumu I (2005) 223-247. Kırşehir.

Cin A. (2012). Yûsuf ve Züleyha Hikâyesi, Akdeniz Üniversitesi Yayınları. Antalya 2012.

Gölpınarlı A. (1953-54). "Burgazî ve Fütüvvetnâmesi". İstanbul Üniversitesi İktisat Fakültesi Mecmuası 15/1-4 (1953-1954) 76-153.

Gölpınarlı A. (1955-56). “Şeyh Seyyid Gaybî Oğlu Şeyh Seyyid Hüseyin Fütüvvetnâmesi”. İstanbul Üniversitesi İktisat Fakültesi Mecmuast 17(1955-1956) 25-155. İstanbul.

Gölpınarlı A. (1955-56).“Fütüvvet Hakkında Bazı Notlar”. İstanbul Üniversitesi İktisat Fakültesi Mecmuast 17 (1955-1956) 1-4.

Gölpınarlı A. (2011). İslâm ve Türk İllerinde Fütüvvet Teşkilâtı ve Kaynakları. İstanbul 2011.

Güler R. (1992) "Razavî̀nin Fütüvvetnâmesi” (Fütüvvetnâme-i Kebîr veya Miftâhü'd-Dekâylk fi Beyâni'l-Fütüvveti ve'l-Hakâylk). Basılmamış Doktora Tezi. Marmara Üniversitesi, İstanbul 1992.

Gülten S. \& Yılmaz H. (2014). Razavi- Fütüvvetnâme-i Kebîr. İstanbul 2014.

Kahveci İ. (2005). "Fütüvvetnâmelerin Dini Dayanakları -Çobanoğlu Fütüvvetnâmesi Özelinde-". Haz. M. F. Köksal, Ahi Evran-ı Velî ve Ahilik Araştırmaları Sempozyumu II (2005) 553-563. Kırşehir.

Kasır H. (1993). "Türk Edebiyatında Fütüvvetnâmeler ve Esrâr Dede'nin Fütüvvetnâmesi”. Atatürk Üniversitesi Sosyal Bilimler Dergisi 1 (1993) 107-130.

Kortantamer T. (1977). “Ahmed-i Dâ’î İle İlgili Yeni Bilgiler”. Türkoloji Dergisi VII (1977) 103-138.

Köksal M. F. (2002) "Dâ̂”". Türk Dünyası Edebiyatçılar Yazarlar ve Şairler Ansiklopedisi (Cilt 2). Ankara 2002.

Ocak A. Y. (1996). "Fütüvvetnâme". Türkiye Diyanet Vakfi İslam Ansiklopedisi (Cilt 13) 264-265. İstanbul 1996.

Özaydın M. (2005). "Fütüvvet ve Fütüvvet Ahlâkı". Haz. M. F. Köksal, Ahi Evran-ı Velî ve Ahilik Araştırmaları Sempozyumu II (2005) 685-712. Kırşehir.

Özmen M. (2001). Ahmed-i Dâ'î Divanı. Ankara 2001.

Sami Ş. (2015). Kamus-ı Türkî. İstanbul 2015.

Sarıkaya M. S. (2002). “13.-16 Asırlardaki Anadolu'da Fütüvvetnamelere göre Dini İnanç Motifleri”. 
Ankara 2002.

Sarıkaya M. S. (2008). Fütüvvetnâme-i Cafer-i Sâdık. İstanbul 2008.

Soysaldı İ. (2005). "Fütüvvet ve Ahilik Ekseninde Günümüze Bir Bakış". Haz. M. F. Köksal, Ahi Evran-ı Velî ve Ahilik Araştırmaları Sempozyumu II (2005) 821-828. Kırşehir 2005.

Şeker M. (2005). "Fütüvvetnâmeler ve Ahîlik -Burgâzî Fütüvvetnâmesine Göre-”. Haz. M. F. Köksal, Ahi Evran-ı Velî ve Ahilik Araştırmaları Sempozyumu II (2005) 837-850. Kırşehir.

Topak M. (2016). Ahi Dâ̂̀ ve Manzum Eseri: Fütüvvetnâme-i Tarsîsî (İnceleme-Metin). Çukurova Üniversitesi, Sosyal Bilimler Enstitüsü, Adana 2016.

Torun A. (1998). Türk Edebiyatında Türkçe Fütüvvetnameler. Ankara 1998.

Uludağ S. \& Ocak A. Y. (1996). "Fütüvvet". Türkiye Diyanet Vakfi İslam Ansiklopedisi (Cilt 13) 259263. İstanbul 1996.

Yeniterzi E. (2001). “Türk Edebiyatında Manzum Fütüvvetnâmeler”. Konya Postasl-Akademik Sayfalar 173 (2001) 115-139. Konya.

Yıldırım I. P. (2005). “Eşref B. Ahmed'in Fütüvvetnâme’si”. Haz. M. F. Köksal, Ahi Evran-ı Velî ve Ahilik Araştırmaları Sempozyumu II (2005) 1011-1021. Kırşehir. 
1v1 ol kerīm ü ol kadīim ü lā-yezāl zā'il olmaz kimseye olsa zevāl

1v2 nitelikden`ārī žātıdır anın zikr olan dā 'im șıfătıdır anıy

1v3 bilinen hịç yolı yoḳ pāyānına 'aḳl-1la kimse èrişmez şanına

1v4 çünki ol cümle ana perde-pūş cümle andandır ḳamu hem tọlı boş

1v5 oldı zāhir birligi vaṣfi ile kimse bilmez künhini așlı ile

1v6 hịmetinde kimsene kạāir degil hīç bu fende kimsene māhir degil

1v7 kưu țaşdan aḳıdan āb-1 revān ḩār içinde bitiren hem gülsitān

1v8 nārı gülşen eyledi hem ḩārı gül ḳulı sulțān eyler ü sulțānı ḳul

1v9 şol ḳasır kim görinür bu yèrcedir ol felekden bunda beş yüz yılcadır

1v10 ètdirir ayı işāretle dü şaḳk bil hakikikatde èdendir anı hakk

1v11 toprak içre bitürir altun gümiş arı bal eyler vèrir şekker ḳamış

1v12 ebr-i nīsānı göricek hem șadef bir iki ḳațreyle bulınca şeref

1v13 ka' $r-1$ deryāda olur dürr-i șemin ḳımet ėder hem yesār u hem yemin

1v14 hikmeti çoḳdır hudānın bī-şumār hāạs kullar èdemez cümle şumār

1v15 hayy-1 bāḳi ol durur bil şeksüzin dile alup söylemişgil şeksüzin

9r1 kimse bilmezdi fütüvvetnāmeyi pes ne bilsün ḩırḳayı vü cāmeyi

9r2 diledim bu 'ilmi izhhār ètmege cem` èdüp nāẓile iş‘ ār ètmege

9r3 bilmez idi her kişi ' ilm ü edeb ḳ1lur idi țunb u țunbā pes țarab

\section{SEBEB-İ TELİF-İ KİTĀP}

9r5 tarsūs ehli bu işe ètmiş heves ba $^{\complement}$ żısı dā' iye ètdiler nefes

9r6 bir fütüvvetnāme cem` èt dèdiler şāh-1 merdān yolına git dèdiler

9r7 zìrā hakk yolında bul durur fetā kimse bilmez hakk yolı andan öte 
9r8 hem dèdi ol enbiyālar serveri bir gazāda lā fetā illāa 'alì

9r9 ehl-i țarsūsı̀ içinde bir ' azīz nev-cuvān u așîl hem arı temīz

9r10 āḩi ḳılmış anı bir şehr bir ulu içi țaşı olmış anınla țolu

9r11 ehl-i țarsūs bir vücūd ol cān durur halk ma' den olsa ol bir kān durur

9r12 şehr halkı̣ bir șadef ol dürr durur gör ki nedür sözleri hep dürr durur

9r13 ansız olsa mahfilin hiç dadı yok ansız olan șoḥbetin bünyādı yok

9r14 ger velīme ola ger da'vet durur șohbet ansız olsa bir mihnet durur

9r15 sevmese anı ulular ger n'ola şimdi münḳād oldı ḥașṣ u 'ām ạa

9v1 özi yigit sözleri şeyhānedür șorur ol dā'im gerek şeyḩe nedür

9v2 himmeti ' alā vü çoḳdur ni' meti ni 'metinden daḩı artık himmeti

9v3 ḥātem-i țaydır zamānında bugün ehl-i țarsūs hep amānında bugün

9v4 hem sahāvet hem şecā' atdır işi vehm èder hem heybetin gören kişi

9v5 heybetin gören kişi rüstem șanur ni` metin gören kişi ḥātem șanur

9v6 kadd-ı bālāsı durur serv-i çemen ḩațț-1 reyhānı durur müşk-i hoten

9v7 țāḳ-1 ebrūsın gören șanur kemān çeşm-i fettānıy gören diler amān

9v8 aḥsen-i șūret görinür șūreti șūretinden daḩı ahsen sỉreti

9v9 yüz țutıpdır bu yola țālib ḳatı kim binüben bu yola sürer atı

9v10 bir nașịhatdür çün ètdiler țaleb ahī yolında nedir 'ilm ü edeb

9v11 bildigünçe ben de birḳaç söyledim gerçi küstāḥlı̣̣dı līkin eyledim

9v12 gerçi tọgrı söz acı gelür veli yegrek oldır söyleye pes hạk yolı

9v13 dèyelim bildügimizi ey ahs luṭf èdüp ḳulaḳțutasın sen daḩı

9v14 cem -i māl ètmek degildir aḩ̄ilık hırș-1la gitmek degildir ahīlı̣

\footnotetext{
1 “Ali’den başka yiğit yoktur”
} 
9v15 dünyaya țapmaḳ degildir ahîilık

dīnini șatmaḳ degildir aḩillı̣

BĀB-I DER-BEYĀN-I ŞEDD-NĀME

23r2 sālik olanlar nice ètmek gerek ne'yleyüp nice yola gitmek gerek

23r3 n'eylese seccādeye lāyık olur n'eyleyicek ahīilı̣̣ bāyı̣̣ olur

23r4 bile erkān-1 hakikikat ne ise vara ādāb-1 țarikat ne ise

$23 r 5$ bu şerā iț ne ise bile anı şüphen olsa ḳandıra ya' nī seni

23r6 hurde-bīn ola yolında key ulu gördügini bile kim uṣlu delü

23r7 kendünin ulu tevellāsı ola gayr-1 hakkḳdan ḩōş teberrāsı ola

23r8 sālik olup kendi yol varmış ola yol bilene özüni vèrmiş ola

23r9 i`c tikādı muhkem ola her işe olmış ola ehl-i şedd yigit pāşa

23r10 pïr elinden içmiş ola ol kişi bu yol içre yoḳ ola hịç teşviş̧i

23r11 zīrā şeddin aṣlı var bilmek gerek ana göre olda şedd vẻrmek gerek

23r12 bu țariki bilmese olur harām ma 'nādan ne bile çün bilmez kelām

23r13 niçeler palheng-i hakịikat dèdiler dahı meftūl-i țarikkat dèdiler

23r14 hem sirişt-i ma' rifet dërler dahy $b^{c}{ }^{c} \dot{z} 1$ şöyle şed dèrler ey aḩَ

23r15 ba'zılar dèrler buna hablü'l-metīn hem daḩı dèrler ' ale'l-vāṣli'l-yaḳinn

23v1 niçeler dèrler șıātạt-1 müstakīim pīr elinden ḳuşanan olmaz saḳīm

23v2 niçeler hādī sürādık dèdiler kuşanur haḳk yola șādıḳ dèdiler

23v3 daḩı şeddin yẻdi şarțı var bilin ḳuşanurken ol yėdi şarțı bulın

23v4 bağlaması yèdidir hem çözmesi bu yėdi gerekdir anın cümlesi

23v5 biri gökden biri yılduzdan durur biri a żāà birisi yerden durur

23v6 zỉrā yedi gökdürir yıldız yèdi cümle à‘ żā ne ki var düpdüz yèdi

23v7 anı bil kim yürüdügin yèr yèdi işler işin cümlesi bir bir yèdi

23v8 yedi bag̉laya vü hem aça yedi 
açduġın gele yedi ḳaça yedi

23v9 bag̉la ef ' āl-i zemīmeden yedi gelsün ef ‘ āl-i ḥamīdeden yedi

23v10 buhlı evvel baġla rạ̣met șaçıla bu sehā ḳapusı ana açıla

23v11 bag̉la ikincide ḳahrını anın açıla luṭfı ḳapusı tạrınıy

23v12 bag̉laya cürmi hevāsından gecçe hem ḳanā' at hem rıżāsından gèçe

23v13 țoḳlıḳ u nefsānīden hep géçile bag̉la kim açlık riyāżet açıla

23v14 bag̉layup hem cümle halkdan halḳ̣ı ḳoyup ḥaḳk ḳapusın açasın

23v15 bag̉la mā-lā-ya'nī yè fāhiş sözi ma 'rifet açıla hem ma 'nā gözi

49r1 hem bize münker nekīr ètse su 'āl kim cevābın vèrmege ola mecāl

49r2 dilümize sen cevābı ḳolay èt ol melek ḳullarına de yüri git

49r3 yā ilāhī șavıvèr bizden ḳażā gör içindekīy ola çevre feżā

49r4 haşr içinde gösterivèr aḥmedi ḳolay ola dilime aḥmed adı

49r6 hem șırāṭ üzre şaşırma ayag̉ım gèçer iken zikrin ola țayaġım

49r7 cennet içre aḥmed ile hem-civār eyleyüvèr cümle bayar u diyār

49r8 țoyla didārıy ile anda bizi yā ilāhī sen ḳabūl èt bu sözi

49r9 biz de didārın ile şād olavuz dostlarınla oynayavuz gülevüz

BĀB-I DER- BEYĀN-I TAFȘīL-İ FÜTÜVVETNĀME

49r11 söylegil ey țūțī-yi şekker-ġ̀dā işidenler cān u dil ètsün fedā

49r12 söylegil ey tūtī-yi şekker-nefes kim sözine cān u dil eyler heves

49r13 söylegil ey țūți-yi şekker-şiken șan'atındır çün yine şekker-şiken

49r14 söylegil ey țūṭi-i vahy-i ilāh n’ola saya bu ḳafes olsa penāh

49r15 söylegil ey 'andelīb-i ḩōş nevā çün sözindir dertlü cānuma devā

49v1 söylegil gül-zāra ḳarşu söylegil bu firāḳıı hạālini şerḥ eylegil

49v2 çün senin hāāüni bilen gül durur naġme-sāz olsay bilür bülbül durur 
49v3 söylegil ey bülbül-i ' īsā-nefes gülşen içre eylegil ' ayşa heves

49v4 perdeden çünkim göründi gonca-ter mest oluban bülbül-i şeydā-heves

49v5 işit imdi vèreyim gülden ḩaber kim ne vaḳtdir bülbüle ḳıldı eser

49v6 çünki ibrāhīmi nemrūd-1 la ìn mancını ̣ ile oda atdı hemīn

49v7 anıy ile gitdi bülbül bile anıy içün geldi bülbül dile

49v8 haḳk te âlā bülbüle dèr ey ża î if ḳullarım içinde yoḳ senden nahîif

49v9 düşmenim şerrine uğradı ḩalil sen n'içün geldin bile dèdi celīi

49v10 dẻdi bülbül yā ilāhì yalınuz dostı1ı ḳoyamadım ben ṭoğrı söz

49v11 ol ne olsa ben de oluram dedim oda girse ben de girürem dèdim

49v12 tanriya hōọş geldi ol dem bu kelām odı ḳıldı ana da berden ${ }^{2}$ selām

$49 \mathrm{v} 13$ dilegin ne ise benden dile der çünki dostım ile geldin bile dèr

50r1 dèdi bülbül yā ilāhī yā kerīm biy bir adın ne ise olam kelim

50r2 bin bir adın bana ögret ey hudā zikr èdüben olmayam gülden cüdā

50r3 güle ḳarşu dā'imā zikr eylesem 'āşı̣ oluban seni fikr eylesem

50r4 sen özüni anda göstergil bana zārı ḳılup ag̉layam ḳarşu saja

50r5 bin bir adın vird èdinem her seher firḳatimden on bir ay vèrem haber

50r6 hakkk ḳabūl eyledi anıy sözüni bülbüle gösterdi gül de özini

50r7 bin bir adın ana ta ${ }^{c}$ lim eyledi ol güle ḳarşu ötüben söyledi

50r8 şimdi göricek güli bülbül öter șanasın kim cānını oda atar

50r9 anıy içündir hezār destān ana ünin işiden kişi ḳalur țana

50r10 tayrı adın gül göricek zikr èder çün güli görür cemālin fikr èder

50r11 geldik imdi bu fütüvvet sözine ötelim biz de fenā gül yüzine

\footnotetext{
2 “Ey ateş! İbrahim'e karşı soğuk, serin ve selamet ol!” (Enbiyā Suresi, 69. ayet)
} 
50r12 bu fütüvvetdir bizim gül-zārımız ötelim biz dahı dinle zārımız

50r13 ben bu 'ilmi cümle tafșil èdeyim cā-be-cā kimisini te' vìl èdeyim

50v1 mücmel olmasun mufașșal olsun ol ne var ise cümle dile gelsün ol

$50 \mathrm{v} 2$ bu fütüvvet 'ilmidir 'ilm-i temīz her ki 'āmil olsa ol olur ' azīz

50v3 bu fütüvvet 'ilmidir ' ilm-i şerīf dīni olmaz 'āmil olanıy ża' îf

50v4 bu fütüvvet 'ilmidir 'ilm-i ḳadìm bilmez anı ḳımetini her le 'ìm

50v5 bu fütüvvet 'ilmidir 'ilm-i ilăh anlayamaz anı her ehl-i günāh

$50 \mathrm{v} 6$ bu fütüvvet 'ilmini her kim bile 'āmil olup anı̀ ile iş ḳıla

50v7 niçeler bilmedi anın ḳadrini her yėrin amma gözedir șadrını

50v8 niçeler buna riyālar ḳatdılar șallaşuban dīni arda atdılar

50v9 niçeler ḍall oldı bunda hem muḍıl niçeler ġavġālar ile kạāl u ḳîl

50v10 niçeler bāṭıl iş içün yıldılar niçeler hakḳ söyleyene güldiler

50v11 fāniye dil vèrdiler ḳoyup haḳ1 niçesi hakḳkı ḳoyup oldı şaḳi

50v12 hịle vü fitneye düzdiler yolı öyle mi gerekdir ey tanrı kulı

50v13 meskenetden bildiler bu yolı bil yola var her kimde vardır ḳāl u kịil

51r1 bu hudā șofrasıdır bil ey aḩi hem 'ali șofrası hem cömerd dahı̆

51r2 gel kerem ḳıl sen buya ḳatma harām bu nașiḥat sana yèter ve's-selām

51r3 dürlü dürlü şöhreti ḳovsay gerek hakḳ̣̂ țutup şöhreti ḳosan gerek

51r4 bu fütüvvet 'ilmidir ' ilm-i hayā anı kimi țuta vü kimi ḳoya

51r5 var durur bu ' $i l m-i$ nef ' $\bar{i}$ bì-ḳıyās bī-nihāyetdir ėdemezler ḳıyās

51r6 oturup țurması vü hem yèmesi söyleyicek sözi nice dèmesi

51r7 terbiyet ède ahī hem bildüre sākin ède nefsini hem öldüre

51r8 kime ug̉asa vère evvel selām söyleye kim olsa luțfiyla kelām 
51r9 ahi ì begler ḳapusına varmaya cehd ède zāalim yüzini görmeye

51r10 ger żarūret olur ise varalar tọgrı söyleyüp nașịhat vèreler

51r11 hem ahī bu 'ilme çoḳ ' izzet ḳ̂la hem bu 'ilmi bilene hürmet ḳla

51 r12 ben bu 'ilmi türkīce naẓm eyledim bu fütüvvetden nice söz söyledim

51r13 anlaması vāżı̣̆ olsun deyüben türkỉ yazdım çoḳ ' ibāret ḳoyuban

51v1 yazayım şimden gèrü bir niçe fașl cümlesine hạậl olan nedir aṣl

51v2 anı bir bir yine tafșîl èdeyin aplasunlar deyü te ${ }^{c}$ vil èdeyin

51v3 yazayım bu bāb içinde yèdi bāb her birisi bābıj olsun bir kitāb

51v4 zirā gördim cümle eşyādır yedi èdeyim bir bir beyān nedir yėdi

51v5 anlar isen yürüdügin yer yėdi yèdi ā̌ zādır ḳamusın bezedi

51v6 başı üzre yedi devvāre yedi işin üzre anda seyyāre yedi

51v7 yẻdidir muṣhaf mekānıdır yedi andaki seb' a'l-meșānīdir yedi

51v8 hafta içre gün yedidir dün yedi ka' beyi eyle țavāf her gün yedi

51v9 secdeye emr olınan $\bar{a}^{c} z a \bar{a}$ yedi secde ḳılmayan işi ġavġaydı

51v10 oruç ayında resūlu'llāh dèdi kadri isten olsa yigirmi yedi

51v11 öyle olsa biz de yazdık yedi bāb eyleye haḳk umaram kim fetḥ-i bāb

51v12 yā ilāhỉ eyle āsān sen bize yazuban tā başlayalım bu söze

58r1 dilümizle biz seni yād èdevüz toğrı ādemler yolına gidevüz

$58 \mathrm{r} 2$ eyleyesin tevbemizi sen kabūl hem şefā' at ède bize ol resūl

58r3 yā ilāhi umarız luṭfin hemīn dūzah içre ḳala ol mahrūm la in

BĀB-I SEVVOM DER- BEYĀN-I ḤIKĀYET-İ ŞīT NEBí ' ALEYHI SELĀM

58r6 bāb-1 üçinciyi dahı dinlegil n'eylemiş ol şît nebì aplağıl

58r7 dinlegil kim dünyāda ol n'eylemiş dünyāda ol ḳanḳı șan`at işlemiş

58r8 dünyāda çün evvel ol cullāh imiş cümleten cullāhlara ol şāh imiş 
58r9 anladın ḩod hakḳ te āāà n'eyledi uçmaḳ içre südi panbuḳ eyledi

$58 \mathrm{r} 10$ anda incīr vèricegiz yaprag̀ 1 oldığı yerde hạạa ādem yaǵı

58r11 anda panbuḳ eyledi südi ḳodı dünyāya çekirdegin al gel dèdi

58 r12 anı cibrīil aldı geldi dünyāya ekile panbuḳ ola ādem yèye

58r13 ekilüp yayıldı cümle dünyāda dünyāda yayıldı bilişe yāda

58v1 çün egirdi anı havvāa anamız bilüriz kim anamızdır yanımız

58v2 tokudı bèz eyledi şît nebī dèdi ādem ataya gey yā ebī

58v3 vèrdi bir tennūrelik bèz ādeme bẻline bag̉ladı èrdi ḩōş deme

58v4 șofra yaydı şì ādem öyine sünnet oldı șofra yaymak șonına

58v5 ger șoralar evvelā kimdir ḳonık şīte ādem ḳondı bil tanrı țanık

58v6 kesdi etmek evvelā şît nebì hōş țoyurdı etmek ile ādemi

58v7 şìte ādem çoḳ du ālar eyledi raḥmet ètsün tanrı dèdi söyledi

58v8 fūța țutunmak bile andan durur apladın tennūreyi kandan durur

58v9 dünyāda tennūrenin aṣlı budur ayladın hōod yaprag̣ın aṣlı nedir

58v10 kardaşından yanına kim geldise lāzım idi şite kim etmek kese

58v11 toḳıdugıından vèr dẻdi bir fuța 'avretini setr èderdi kim țuta

58v12 kim dilerse anlarınla bulına vėre gömlek dünyāda hakḳk ḳulına

58v13 her ki ' uryān țonada bunda ahī anlarıy șaffinda kopa ol dahı

77r1 şîr-i hakḳ idi ‘ aliyyu’llāh idi 'ālim idi hem veliyyu'llāh idi

$77 \mathrm{r} 2$ şîr- veş depren bu yolda ey aḩ $\overline{\mathrm{i}}$ hōọs fetādur deyeler sana daḩı

77r3 zü'lfiḳārı lāyı alġıl dilüye gelmeye ḳorḳudan iblis yoluna

77r4 māsivāyı lā ile ḳaț eylegil ḳalma anda dā'im illā söylegil

77r5 lāne kılsan bil fenāsın ey cuvān ġayrı ḥaḳḳı bilesin lā dèr hemān 
77r6 her ki illā buldı ol buldı beḳā bil ki şeksiz èrdi ḥaḳḳa muṭlaḳā

77r7 gayrı ile ayruk olmaz ol fetā külli şeyle bulmaz ol dahıı cezā

77r8 șofra yaydı şit nebī oldı ahi șofra yay sen daḩı olasin aḩ $\overline{\mathrm{i}}$

77r9 tọkıdı bèz hem yalın țonatdı ol anın içün oldı hakḳa țoğrı ḳul

77r10 sen de yalın țonadırsan ey cuvān vèreler yarın sana emn ü amān

77r11 nefsine bıraḳdı çün ādem șuçı dẻdi yā rabb sen ulusın ben kiçi

77r12 anı̀ içün hakḳ anı ' afv eyledi raḥmet-i ḩ ānıyla anı țoyladı

77r13 ètdügini sen de nefsinden bilüp ağlayasın dā imā miskīn olup

77v1 sen dahı eksigini bil ey aḩ $\overline{\mathrm{i}}$ yarlıgaya haḳk çalab seni dahı

77v2 apladın $\mathrm{m}$ kim durur yèdi kişi hakk yanında anlarıy bitdi işi

77v3 dèyeyim ben anları yine saya sen ḳulagiın țutasin benden yana

77v4 biri ādem biri şit biri halīl biri yūsuf kim fetā ètdi celīl

77v5 biri yūşa' hem muhammed hem 'alī kimisi peyġamber ü kimi velì

77v6 kimine dèndi fetā kime aḩi hem ahīi idi bular hem şeyḩ dahı

77v7 ger fetã isen bulardur piş̧rev ger aḩi vü şeyh isen der pes birev

77v8 bu idi bāb içre bunları dèdik her birinin hāalini şerh eyledik

77v9 apladınsa sen de öyle èdesin anların șuyınca sen de gidesin

77v10 bu idi bāb bunda hațm oldı hemin kuvvet ètdi bize rabbü'l-ālemīn

77v11 bu fütüvvetnāme uş oldı tamām yazup anı hațm ḳıldıḳ ve's-selām

BĀB-I DER- BEYĀN-I MEŞĀYIḤ-NĀME VE ȘIFATHĀĀDĀBHĀ BĀB-I SĀLIKK

78r1 ḳanı ol țālib ki şeyh isterdi ol mürşid olup göstereydi aya yol

78r2 ḳanı ol mürşid gerek bana dèyen gelsün imdi èdeyin kimdür uyan

78r3 kanı ol șādık ki yolda cān vère hāanumān u māl u genc u kān vere

78r4 ḳanı cān terk eyleyen cānān içün vèrmeyen cān bulmadı cānān içün 
78r5 cānını terk eyleyen buldı anı terk ėderem cānımı dẻyen ḳanı

78r6 èrmedi cānānına cānın seven bulmadı makșūdını dünyā ḳovan

78r7 dünyā ile dīn cem` olmaz bilin düşmen olan yẻre dōst girmez bilin

78r8 ḩalḳ èdelden berü dünyāyı huudā sevmez anı kendüden ḳıldı cüdā

78r9 her ki dünyā sevse ol bulmaz ḥaḳı göylini ana vèren olur şāḳī

78r10 kendüye hakk anı maġżūb eyledi terk èden kişiyi mahbūb eyledi

78r11 dèmedi mi anı ol hayru'l-beşer terki içün bize ol vèrdi ḩaber

78r12 āḩiret ehline hem dèdi ḥarām sem 'ine èrişmedi mi bu kelām

78r13 dünyā ehline harāmmdır āhiret çünki hayvān yėmedir ol āhiret

78v1 her ki ehlü'llāhdır ikisi dahıı çün harāàm oldı vü terk èt sen dahıı

78v2 kim ki terk ètdi ise èrdi haka bil ki şeksiz hakkḳa èrdi muțlaḳā

78v3 her ki ḥaḳk sevgüsini ḳıldı ḳabūl hergiz ol dünyā içün olmaz melūl

78v4 ādemi kim evvelā halḳ eyledi ' arż -1 șan' at èdüben halḳ eyledi

78v5 karşu țutdı ādeme her șan 'atı kim kabūl eyleyeler ol mihneti

78v6 gördi ādem șan`atı her ne ki var her biriniz birin eylen ihtiyār

78v7 her biri bir șan`atı ḳıldı ḳabūl hịç ḳabūl eylemedi bir niçe ḳul

78v8 dèdi hakaḳ kim siz n'içün ḳılmadınız bunca șan' atdan birin almadınız

78v9 dèdiler kim biz seni ḳıldık kabūl sen yètersin bize olmazız fużūl

78v10 hakk te āāā dedi kim ‘izzim ḥaḳ1 olmaya dünyāda sizden muttakì

78v11 sizden ayru olmayam ben dünyāda benim ile ḳalasız dünyā gide

78v12 siz baya gözgü olasız göreler size ḳarşu mest u hayrān țuralar

78v13 kim beni görmek diler görsün sizi sizde göre beni hem olan gözi

87r1 bilmeyen șanur anı halḳdan kişi kim durur anı bilür bilen kişi 
87r2 hakḳ anı̣la biledür gayrı degil hakḳ iledir ol dahı ayrı degil

87r3 evliyālar cümlesi münḳād ana ḳuțb-1 `ālem oldı çünkim ad ana

87r4 mürşid -i kāmil durur ol bilesin isteyesin k़anda ise bulasın

87r5 niçeler ölçümlı̀̇ıla şeyhlenür niçeler kendözini şeyḩim șanur

87r6 olmaya kim sen de ölçüm olasın 'ām olanlar yègdir andan bilesin

87r7 yā ilāhì bizi ölçüm eyleme ölçüm ile bizi de güm eyleme

87r8 kurtarıvèr zerḳ u sālūsdan bizi kim görinmeye bize zerrāk yüzi

87r9 zāhid-i pindār olandan ḳılmaġıl her gèce bī-zār olandan ḳılmaġıl

87r10 kendi cezbenden bize luțf eylegil kudretin diliyle gel dèp söylegil

87r11 kim tesellüs ètse andan bīzārām şimdi sīmāsından anı sezerem

87r12 sen tesellüs ètmeden kurtar bizi inşa'llāh görmeye sālūs yüzi

87r13 'aş̣ḳı ile sen bizi ḳıl āşina zāhid-i sālūs göricek yā şinā

87v1 yā ilāhī ' aşḳıy ile hem-rah èt kandasavuz anıy ile gümrah èt

87v2 ol kulaguzz ola saja varmaga esşigüne yüz sürüp yalvarmagia

87v3 n'eyler ise ' aşḳın eylesün bize 'aşḳ ile varıp baḳavuz ol yüze

87v4 'aşḳıı ile öldürüben ḳıl fenā yarın anda görmeyem renc $u^{\text {' inā }}$

87v5 'aşḳıı ile ḳıl mu' anber göylimi 'aşkııı ile ḳıl mu'ațtar gönlimi

87v6 'aşḳıı ile cānı handān eylegil kisve gitsün ' aşḳa ḳurbān eylegil

87v7 hem huarābātına 'aşḳıı sen yètür küllī varlık hem ḩarāb olsun yitür

87v8 dertlü gönlim oldı ' aşḳıı 'āşı̣ıı kim diler kim ola' aşḳıı fāsıḳı

87v9 'aşḳ elinden içmek içün mey diler kim bu meydānı bu göylim key diler

87v10 yā ilāhỉ șunsa 'aşḳı bir ḳadeh içüben mest olsa cān bulsa ferah

87v12 sen nașīb èt bize ' aşkı̣ıdan şarāb mevt èrişüp bizi ḳılmadın türāb 


\section{KAYNAK METIN}
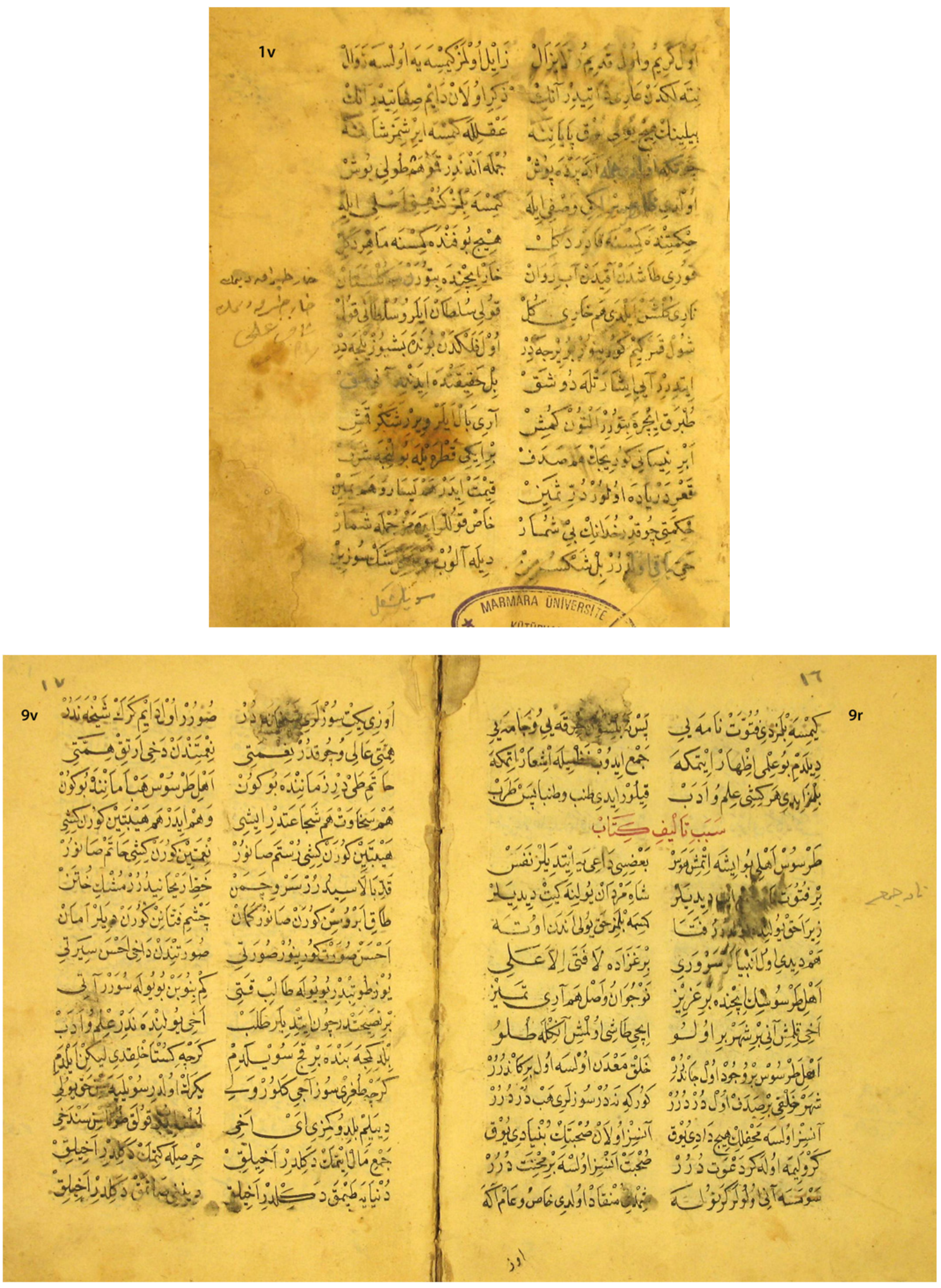


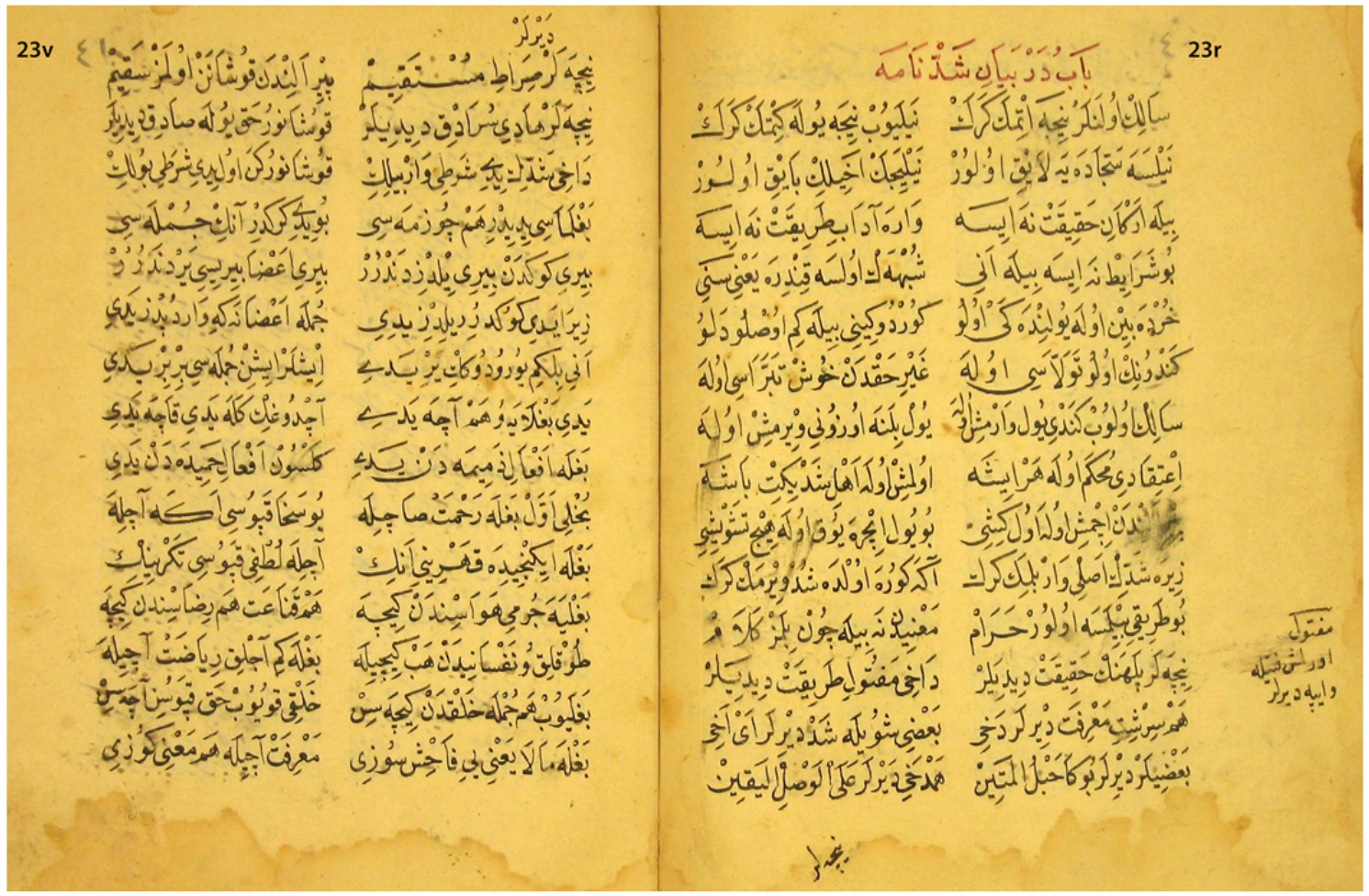

$49 v$

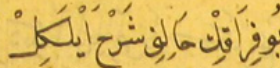

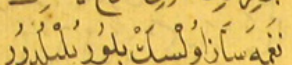

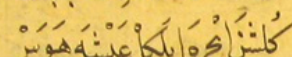
كتن:

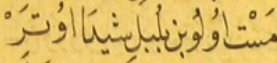

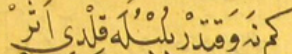

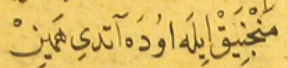

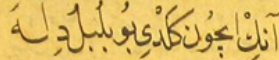

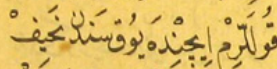

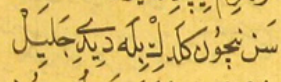

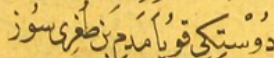

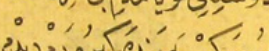

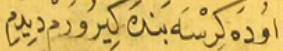

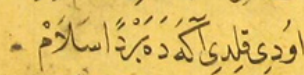

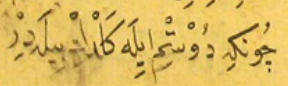

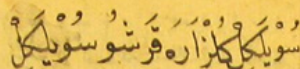

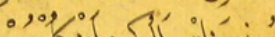

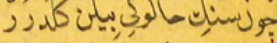

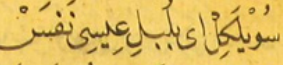

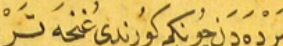
ن́خ

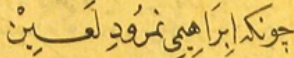

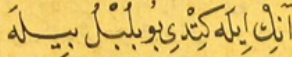

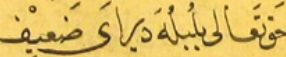

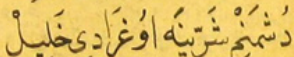

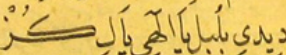

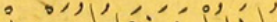

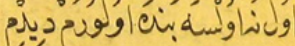

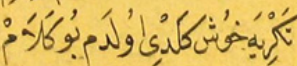

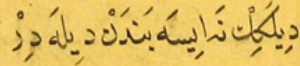

49r

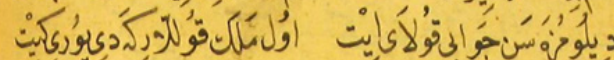

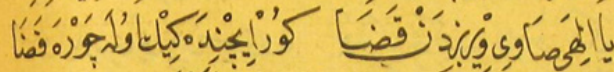

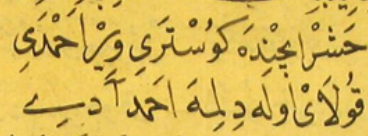

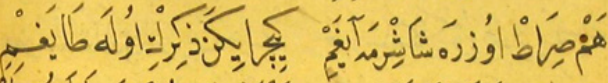

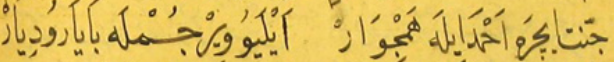

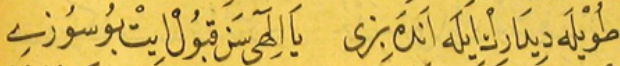

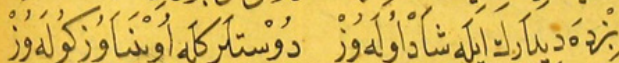
"ú

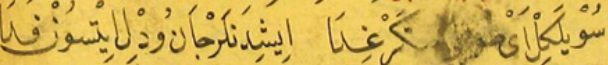

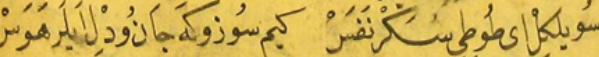

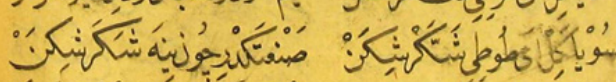

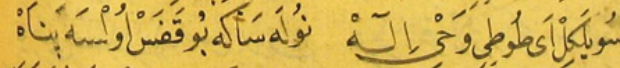

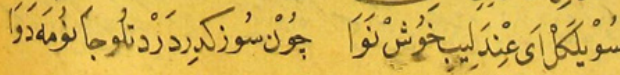




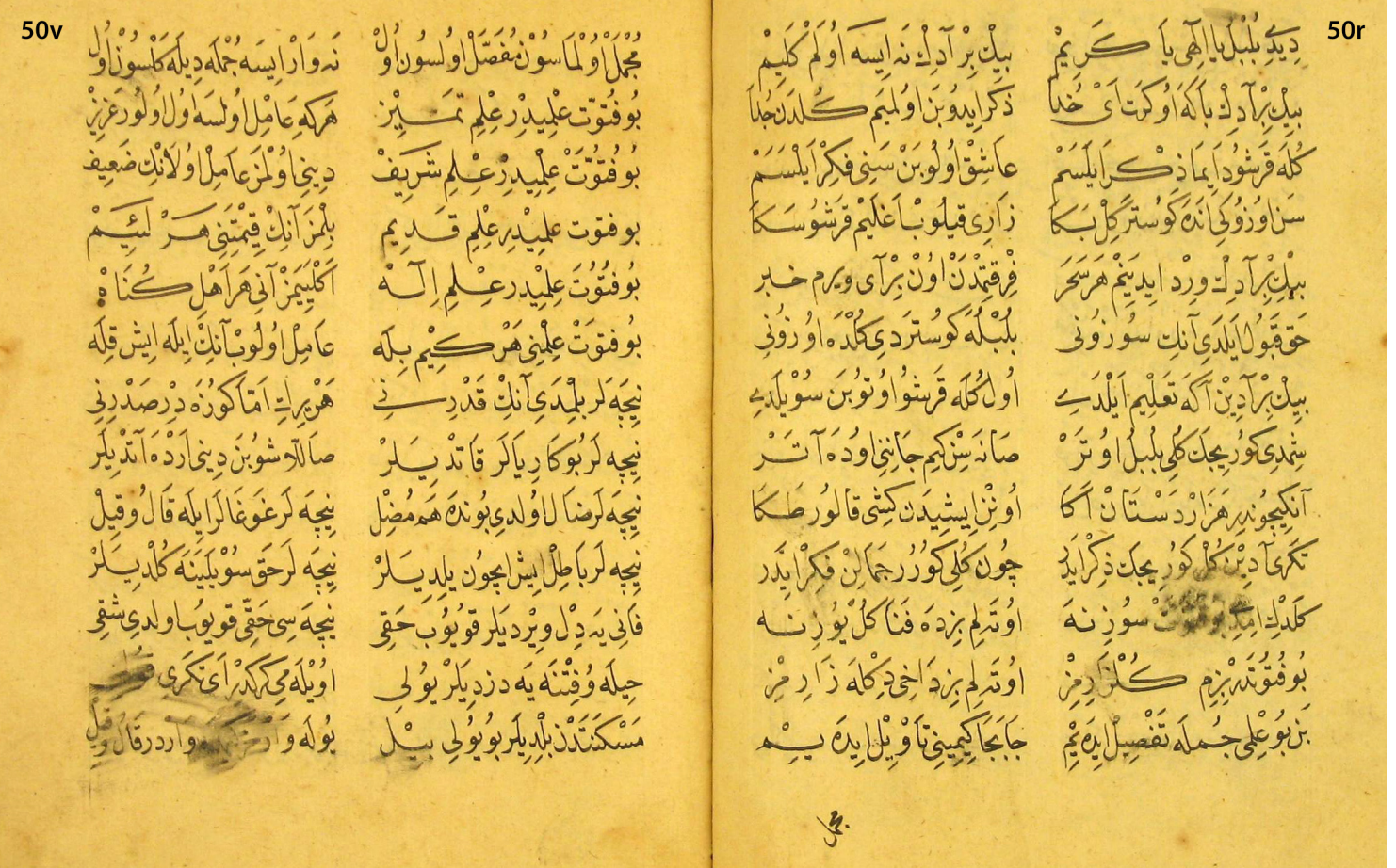

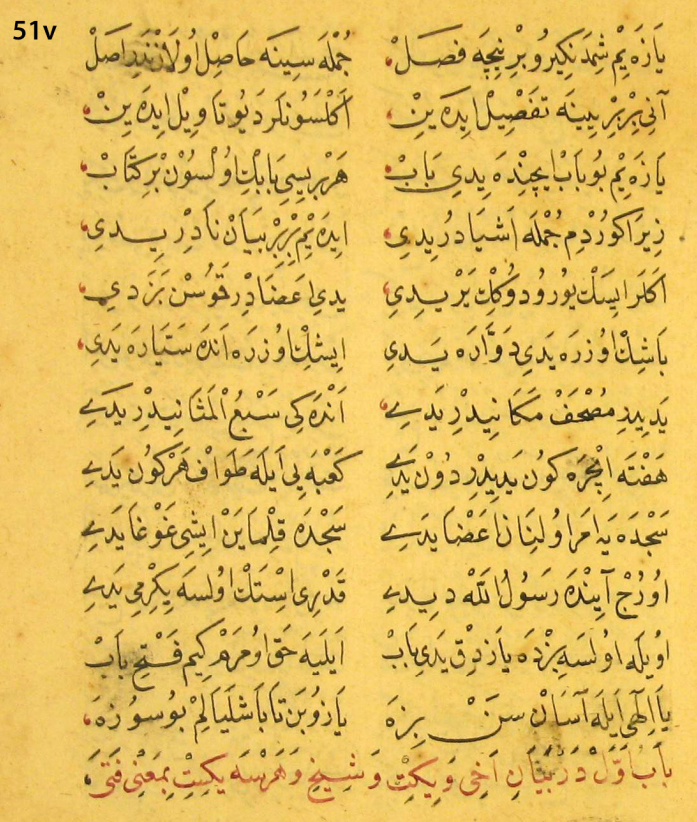

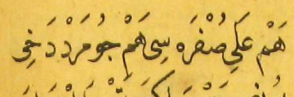

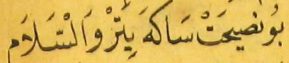

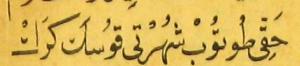

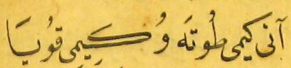

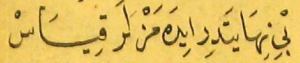

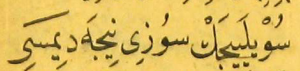

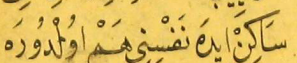

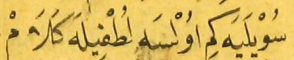

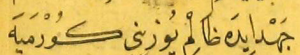

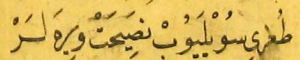

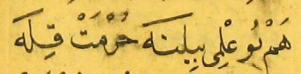


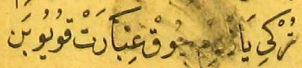

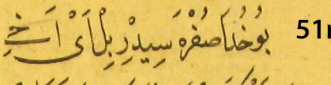

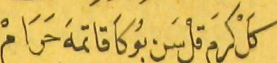
(1...

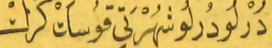

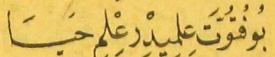

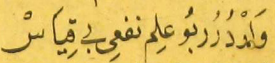

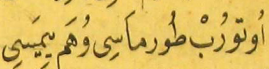
, ر.

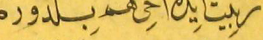

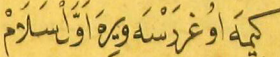

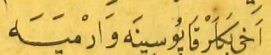

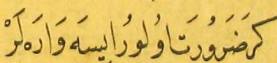

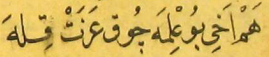
- 0 . …

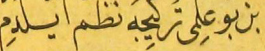

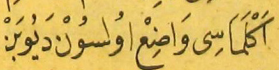
(i)े 


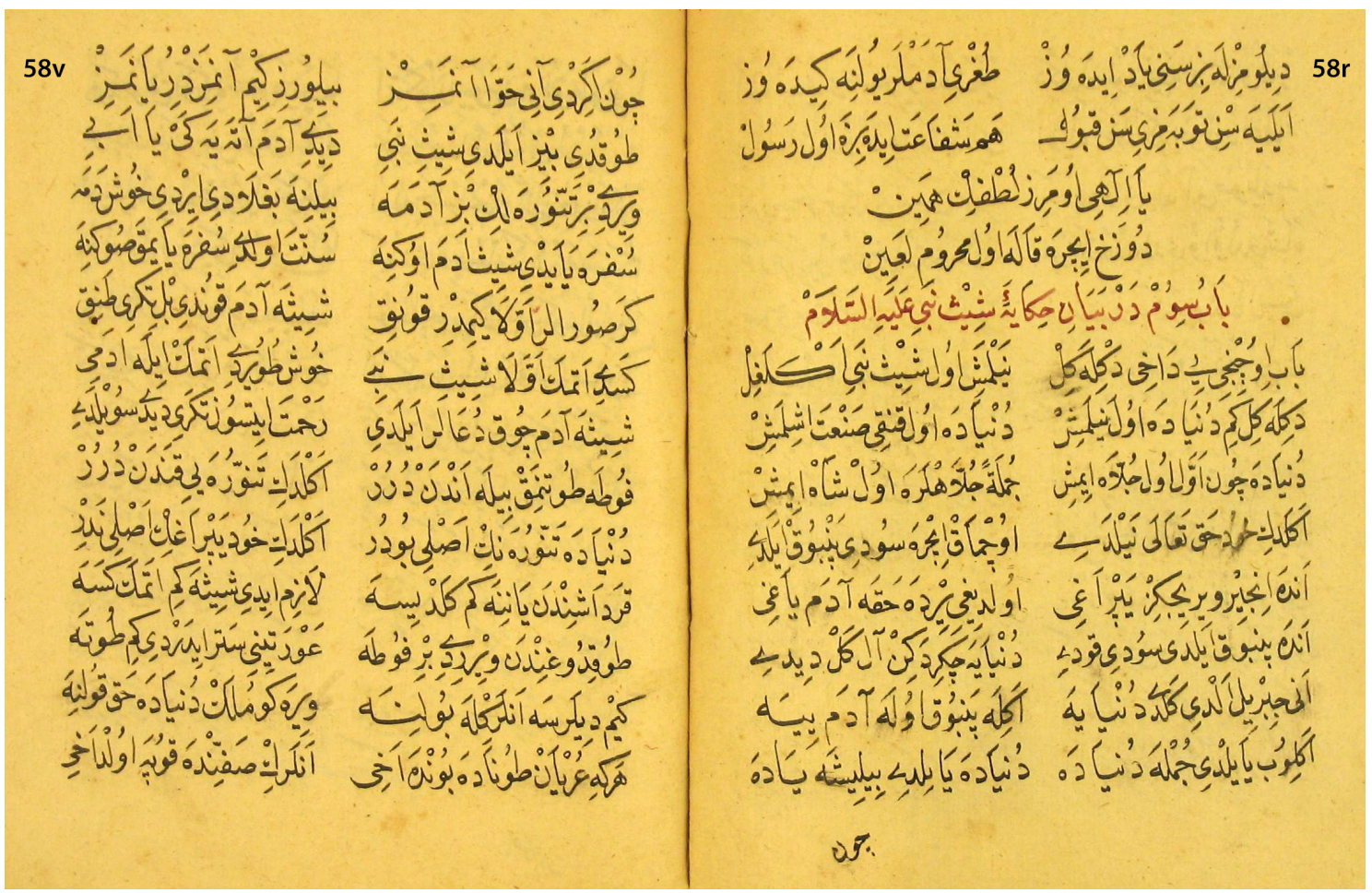

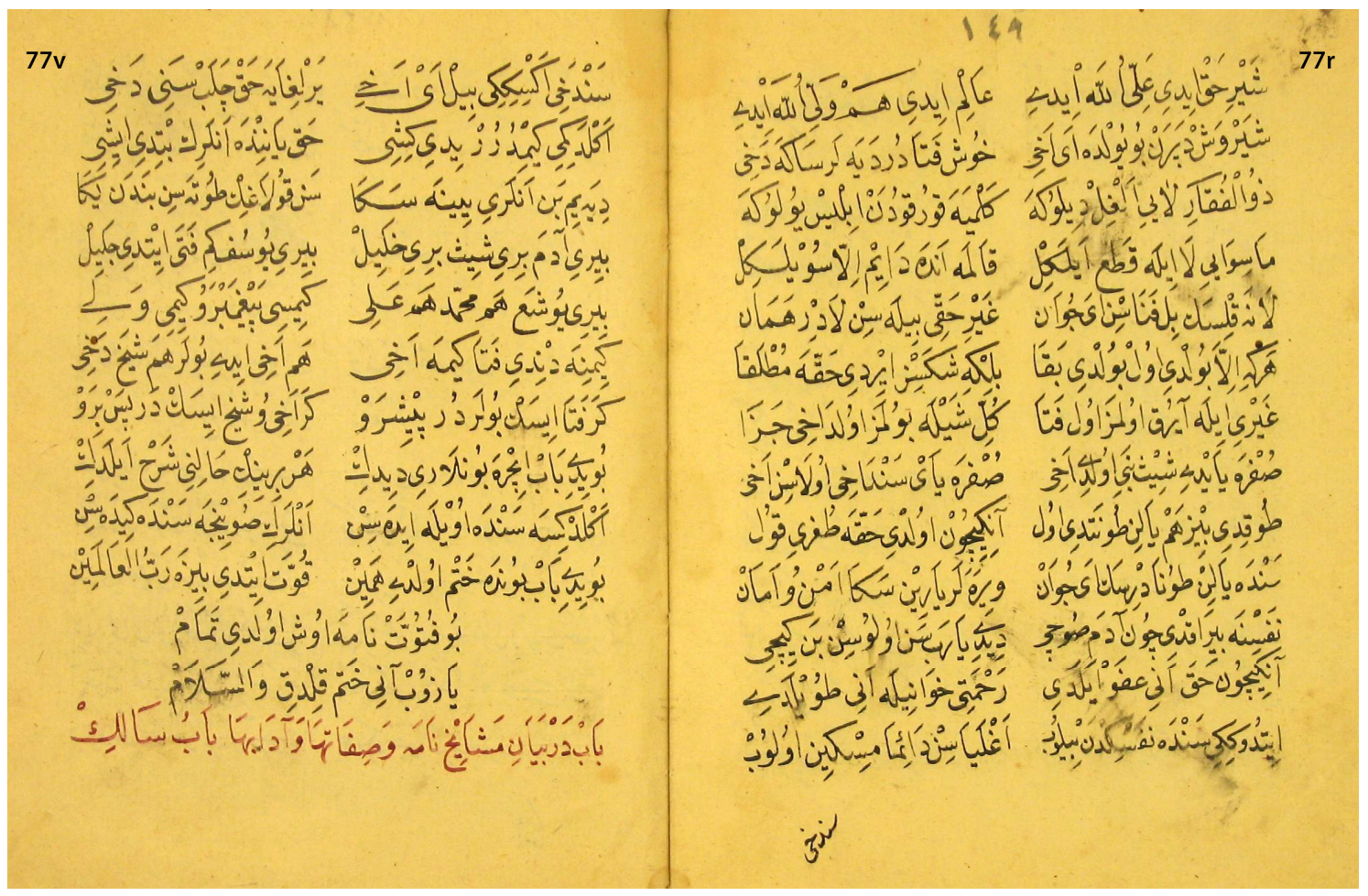




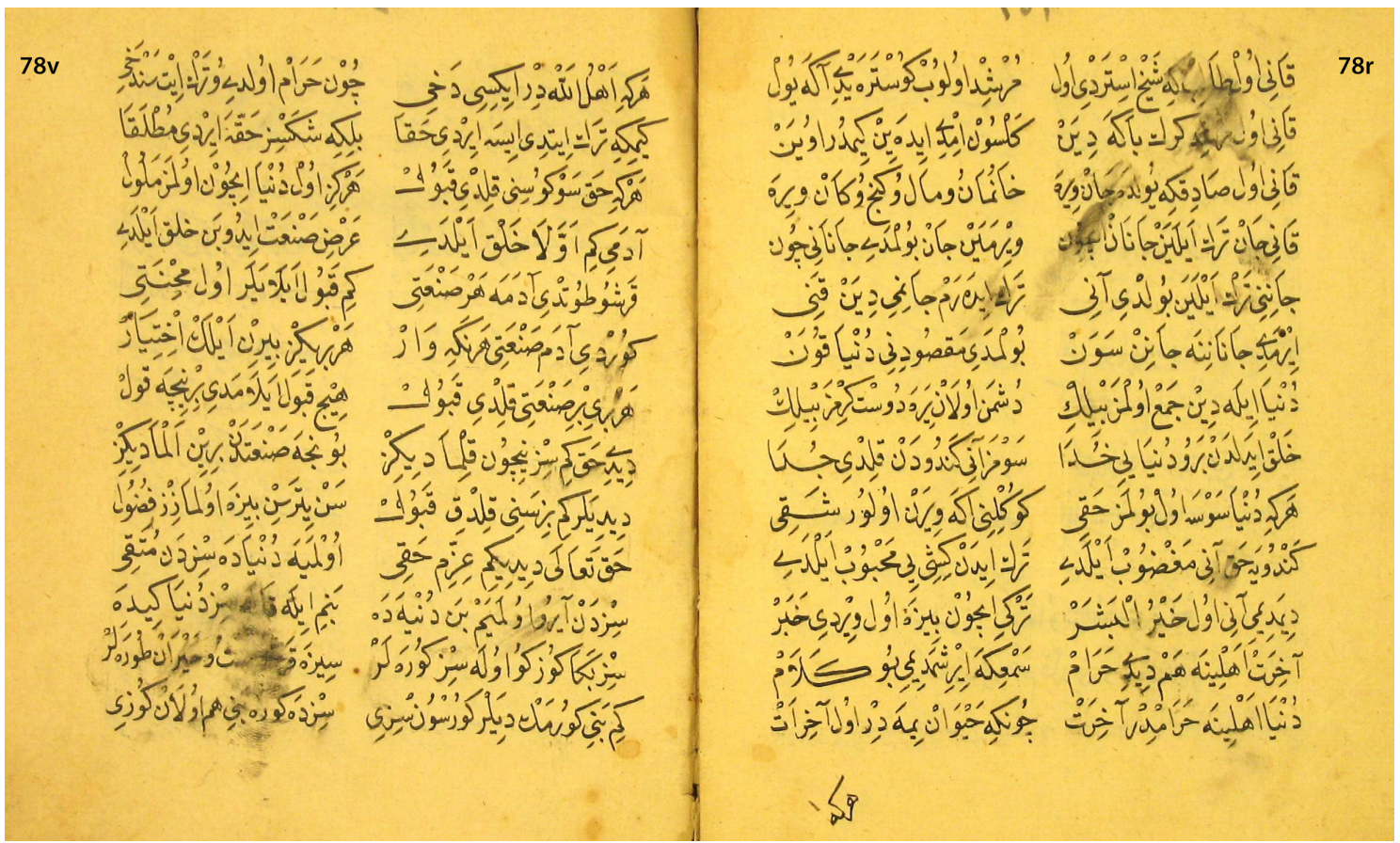

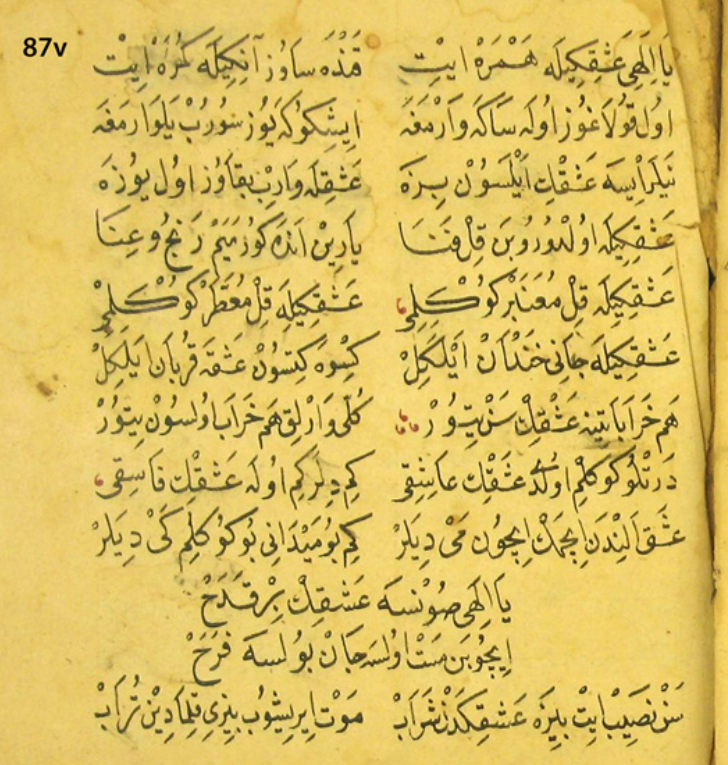

87r

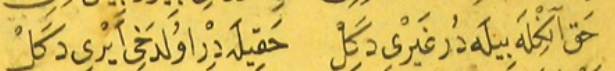

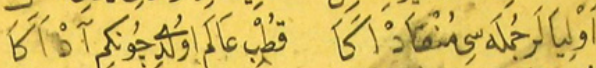
bice "र

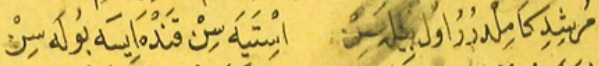

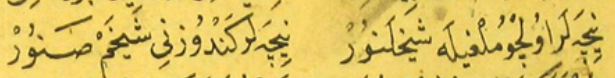

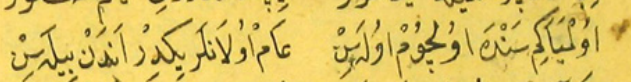

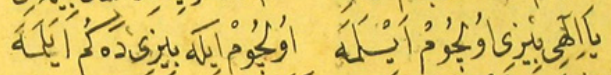

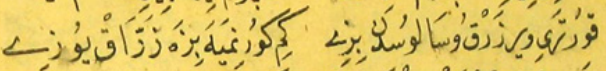

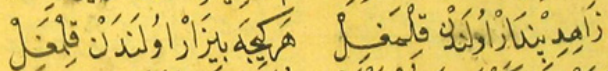

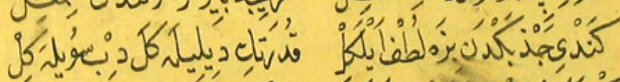
"' (2) 0 \%

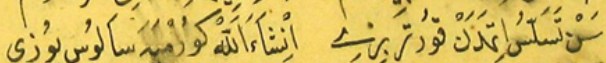

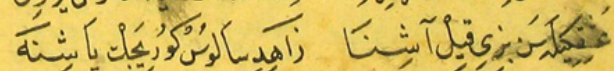
$5)^{16}$ 